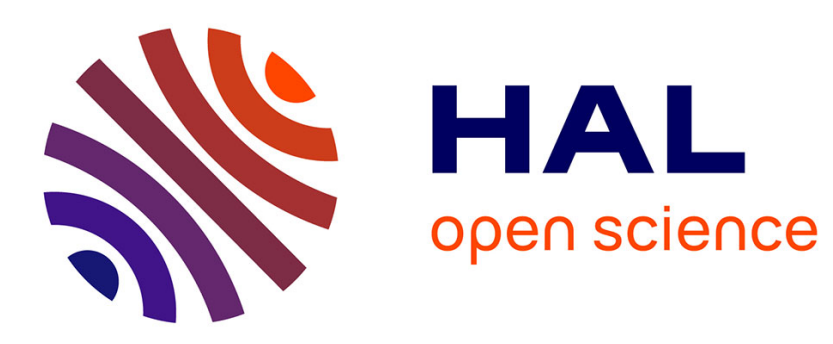

\title{
Synchrotron high-resolution XRD and thermal expansion of synthetic Mg calcites
}

Nicole Floquet, Daniel Vielzeuf, Vasile Heresanu, Didier Laporte, Jonathan Perrin

\section{- To cite this version:}

Nicole Floquet, Daniel Vielzeuf, Vasile Heresanu, Didier Laporte, Jonathan Perrin. Synchrotron highresolution XRD and thermal expansion of synthetic Mg calcites. Physics and Chemistry of Minerals, 2020, 47 (48), 10.1007/s00269-020-01115-5 . hal-02975828

\section{HAL Id: hal-02975828 \\ https://hal.uca.fr/hal-02975828}

Submitted on 23 Oct 2020

HAL is a multi-disciplinary open access archive for the deposit and dissemination of scientific research documents, whether they are published or not. The documents may come from teaching and research institutions in France or abroad, or from public or private research centers.
L'archive ouverte pluridisciplinaire HAL, est destinée au dépôt et à la diffusion de documents scientifiques de niveau recherche, publiés ou non, émanant des établissements d'enseignement et de recherche français ou étrangers, des laboratoires publics ou privés. 


\section{Synchrotron High-Resolution XRD and thermal expansion of synthetic Mg Calcites}

Nicole Floquet, ${ }^{*}$, a Daniel Vielzeuf, ${ }^{a}$ Vasile Heresanu, ${ }^{a}$ Didier Laporte ${ }^{b}$ and Jonathan Perrin. ${ }^{c}$

a Aix-Marseille University, CNRS, CINaM UMR7325, 13288 Marseille, France

b Université Clermont Auvergne, CNRS, IRD, OPGC, Laboratoire Magmas et Volcans, 63000 Clermont-Ferrand, France

c Synchrotron SOLEIL, BP 38, Saint-Aubin, Gif-sur-Yvette, France

* Corresponding author N. Floquet.

Address : CNRS, UMR7325, Aix-Marseille University, CINaM, 13288, Marseille, France.

E-mail addresses : floquet@cinam.univ-mrs.fr (N. Floquet) vielzeuf@cinam.univ-mrs.fr (D. Vielzeuf), heresanu@cinam.univ-mrs.fr (V. Heresanu), didier.laporte@uca.fr (D. Laporte), perrin@synchrotron-soleil.fr (J. Perrin).

\section{Abstract :}

The structural parameters and the thermal behavior of a complete series of Ca-Mg carbonates synthesized at high pressure and temperature (1-1.5 GPa, 1273-1373 K) in the range 0-50 mol\% $\mathrm{MgCO}_{3}$ has been investigated by in situ powder synchrotron high-resolution X-ray diffraction at ambient and up to $1073 \mathrm{~K}$ under self-controlled $\mathrm{CO}_{2}$ partial pressure. The crystal structures are disordered $\mathrm{Mg}$ calcite in the range 1- $41 \mathrm{~mol} \% \mathrm{MgCO}_{3}$, and Ca dolomite at 49 mol\% $\mathrm{MgCO}_{3}$. New calibration curves of the cell parameters for the $\mathrm{Mg}$ content and thermal expansion from ambient to $1073 \mathrm{~K}$ are given. Short range structural effects of cation substitution and ordering and their thermal behavior as a function of $\mathrm{Mg}$ content were identified from three sets of data: the peak broadening, the cell parameter strains and the Raman band enlargements. Both intra- and inter-crystalline levels of compositional heterogeneity are identified and allow splitting the $\mathrm{Mg}$ calcites into two groups: low and high$\mathrm{Mg}$ calcites. The low $\mathrm{Mg}$ calcites (up to $22 \mathrm{~mol} \% \mathrm{MgCO}_{3}$ ) are homogeneous in $\mathrm{Mg}$ content with short range ordering. High $\mathrm{Mg}$ calcite (up to $41 \mathrm{~mol} \% \mathrm{MgCO}_{3}$ ) display domains with different local ordering configurations and similar or slightly different $\mathrm{Mg}$ contents, and to which is added a compositional variation between crystals, as determined by EMP, of the order of \pm $0.8 \mathrm{~mol} \% \mathrm{MgCO}_{3}$. The cation ordering in Ca-rich dolomites similarly occurs in high-Mg synthetic calcites. The role of $\left(\mathrm{CO}_{3}\right)^{2-}$ group ordering is shown to be an important factor in the formation of Ca-Mg carbonates.

Key-words: calcite-dolomite solid solution; RT and high-temperature X-ray diffraction; crystal structure; short range cation order; long range cation order; thermal expansion. 


\section{Introduction}

Among all carbonate systems, $\mathrm{Ca}-\mathrm{Mg}$ carbonates on the calcite dolomite join are the most studied due to their importance as geological and industrial materials. Low to high Mg-calcites are main components of many biominerals, whereas Ca-rich dolomites with Ca excess up to 6 mol\% occur in sedimentary rocks of diverse environments and ages. Most natural carbonates present morphology, structure, composition, stoichiometry, and/or cation ordering deviations from the ideal crystalline structures of calcite and dolomite (Deelman 2011; RodriguezNavarro et al. 2013). Such features may contain information about crystal growth. They may also reflect environmental factors that control $\mathrm{Mg}$ calcite and $\mathrm{Ca}$ dolomite formation and transformation in biominerals and sedimentary rocks.

Optically clear natural (OCN) calcite, dolomite and synthetic crystals on the calcite-dolomite join are commonly used as standards to study the physicochemical and structural properties of natural carbonates. Synthesized $\mathrm{Mg}$-calcites were produced either at high pressure and temperature from solid mixtures (Bischoff et al. 1983; Goldsmith et al. 1958; Goldsmith et al. 1961; Jenkins et al. 2018) or by crystallization in aqueous solutions under ambient pressure and temperature (Glover and Sippel 1967) and references therein, (Zhang et al. 2010). As a reference work, (Bischoff et al. 1983) synthesized up to $24 \mathrm{~mol}^{2} \mathrm{MgCO}_{3} \mathrm{Mg}$-calcites at high pressure (2, 10 and $15 \mathrm{kbar}$ ) and temperature (973K or $1273 \mathrm{~K})$, and characterized the products by XRD and $\mu$ Raman spectroscopy. The Mg-calcites are reported as fully disordered calcite structures and display a nonlinear, but smooth, variation of unit cell parameters and volume with composition up to about $20 \mathrm{~mol}$. \% $\mathrm{MgCO}_{3}$. (Bischoff et al. 1983) reported negative excess volumes changing from negative to positive at 20 mol. \% $\mathrm{MgCO}_{3}$ (Fig. 1). (Zhang et al. 2010) indicate that the cell parameters of $\mathrm{Mg}$ calcites synthesized in aqueous solutions deviate from a simple linear trend above $28 \mathrm{~mol}$ \% $\mathrm{MgCO}_{3}$ (Fig. 1). (Zhang et al. 2010) considered that this non-linear change of structural parameters is related to partially ordered arrangements of $\mathrm{Mg}$ and $\mathrm{Ca}$ and twinning which are well known for compositions close to dolomite (( $\underline{\text { Reeder 1992; }}$ Rodriguez-Navarro et al. 2013; Wenk et al. 1983) and references therein). Thus, the relationship between $\mathrm{Ca}-\mathrm{Mg}$ structural ordering observed by transmission electron microscopy (Fang and Xu 2019; Larsson and Christy 2008; Meike et al. 1988; Reksten 1990; Shen et al. 2014; Van Tendeloo et al. 1985; Wenk et al. 1991) and the cell parameter variations as a function of $\mathrm{Mg}$ content are still a matter of debate and require new structural studies of high quality $\mathrm{Mg}$ calcites of known composition. Further evidence of structural ordering (or not) can be obtained by studying the evolution of the crystal structure with temperature through in situ heating experiments. An interesting relationship between structure and physical property is observed in carbonates in terms of thermal expansion and its relationship with anion group libration and cation octahedra composition (Reeder and Markgraf 1986; Wang et al. 2018). Indeed, calcite displays negative and positive thermal expansions of $a$ and $c$ cell parameters, respectively, whereas dolomite and magnesite show positive, although quite anisotropic, thermal expansions of both $a$ and $c$ parameters. Noting this fact, (Markgraf 
81

and Reeder 1985) wondered about the thermal expansion of the a cell parameter in magnesian calcites, and more specifically about the Ca:Mg ratio at which the thermal expansion of the $a$ cell parameter changes from negative to positive.
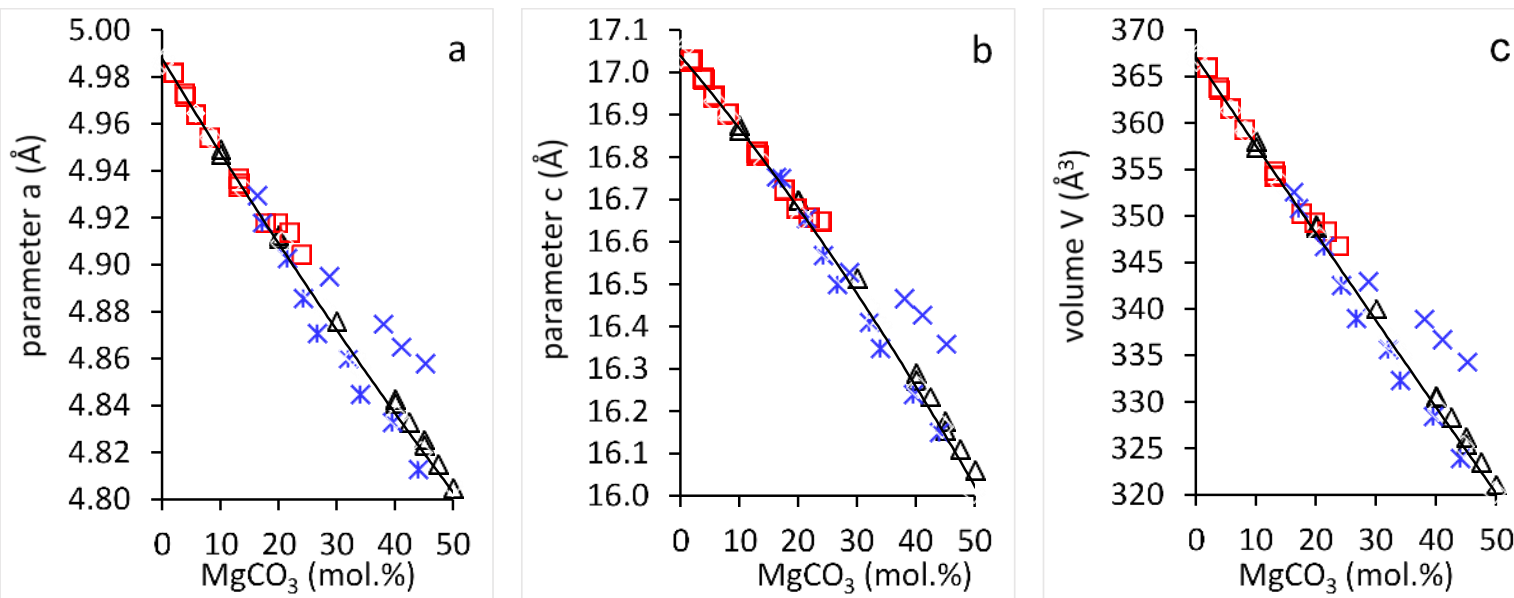

Fig. 1 a, $c$ and $V$ parameters of synthetic calcites according to previous studies. Note the discrepancies above $20 \mathrm{~mol} \% \mathrm{MgCO}_{3}$. Black triangles: Goldsmith et al (1961); Blue stars: Erenburg (1963); blue crosses: Zhang et al (2010); red squares: Bischoff et al (1983). The line in the $V$ - $X$ diagram corresponds to the calibration curve of Jenkins $(2018): V\left(\AA^{3}\right)=366.788-0.9326 \times \mathrm{mol}^{2} \mathrm{MgCO}_{3}$

The present study is a follow-up from a previous one on the same synthetic carbonate samples, already published by our group. The first study is a comprehensive characterization by $\mu$ Raman spectroscopy giving accurate data (both in wavelength position and full width at half maximum (FWHM) peaks of carbonate group vibration bands) on the local ordering of the carbonate groups along the calcite-dolomite join (Perrin et al. 2016). The aims of the present study are (1) to analyze the powder diffractograms obtained by synchrotron high-resolution X-ray powder diffraction (HRXRPD), determine the cell parameters and identify the structural short- and (or) long-range ordering (if any) of Ca-Mg carbonates in the range $0-50 \mathrm{~mol} \%$ $\mathrm{MgCO}_{3}$; (2) characterize in situ the evolution with temperature of the crystal structure of selected $\mathrm{Mg}$ calcites and determine their thermal expansion up to $1073 \mathrm{~K}$ under self-controlled $\mathrm{CO}_{2}$ partial pressure.

\section{Materials and Methods}

\section{Experimental syntheses}

The samples were synthesized at high pressure and high temperature in a piston cylinder apparatus (Perrin et al. 2016). The $\mathrm{Mg}$ calcites cover the range 2 to $50 \mathrm{~mol}^{\circ} \mathrm{MgCO}_{3}(2$ and 5 mol\% step intervals between 2-30 and 30-50 mol\% $\mathrm{MgCO}_{3}$, respectively). The starting materials consist of pure synthetic calcite (Alfa Aesar) and natural magnesite from Brumado 
(Bahia, Brazil). After desiccation in an oven at $383 \mathrm{~K}$, about $60 \mathrm{mg}$ of the mixture were loaded in a $7 \mathrm{~mm}$ long by $5 \mathrm{~mm}$ outer-diameter gold capsule and welded shut. The gold capsule was placed in a salt-glass assembly pressurized and heated for $\sim 96 \mathrm{~h}$ in the piston-cylinder apparatus, at $1273 \mathrm{~K}$ and $1 \mathrm{GPa}$ for compositions in the range 2-30 mol\% $\mathrm{MgCO}_{3}$. For compositions in the range $35-50$ mol\% $\mathrm{MgCO}_{3}$, higher pressure and temperature were selected ( $1373 \mathrm{~K}$ and $1.5 \mathrm{GPa}$ ) to avoid exsolution in the calcite-dolomite solvus as determined by (Goldsmith et al. 1961). Large thick-walled capsules yielded sufficient quantity of crystalline material in a single experiment to carry out different series of analyses while long run durations ( $\sim 4$ days) favored attainment of textural and thermodynamic equilibrium. All runs were quenched by the same procedure at high pressures, by cutting off the electrical power. The quenching time was about $20 \mathrm{~s}$ from $1273 \mathrm{~K}$ to $573 \mathrm{~K}$ and $5 \mathrm{~min}$ to room temperature. After the experiment, the run product was extracted from the capsule, part of it was mounted in epoxy and polished for electron microprobe (EMP), scanning electron microscopy (SEM) and $\mu$ Raman analyses (Perrin et al. 2016), while the remaining was ground and kept for X-ray diffraction (XRD). OCN calcite, dolomite, and magnesite crystals were also analyzed to serve as references. OCN calcite comes from a perfect rhombohedron of unknown origin. OCN dolomite and OCN magnesite come from Azcárate quarry, Eugui, Esteríbar (Spain), and Brumado, Bahia (Brazil), respectively. Note that the number associated with the sample name (e.g. $\mathrm{MgCc} 2, \mathrm{MgCc50}$ ) refer to the nominal composition in $\mathrm{mol}^{2} \mathrm{MgCO}_{3}$ in the starting material. The actual concentrations measured by EMP are given in Table 1.

\section{Analytical Methods}

\section{Synchrotron High-Resolution X-ray Powder Diffraction}

HRXRPD of the samples was performed at the ID22 beamline of the European Synchrotron Radiation Facility (ESRF, Grenoble, France). The instrument is equipped with a double-crystal monochromator $\mathrm{Si}_{(111)}$ and crystal analyzer optical elements in the incident and diffracted beams, respectively. A description of the diffraction instrument is given by (Fitch 2004). The setup allows high quality powder diffraction patterns with high signal/noise ratio, combined with narrow peaks, accurate positions and intensities. The instrumental contribution to peak width (FWHM) does not exceed $0.003^{\circ} 2 \theta$. The typical resolution $(\Delta d / d)$ is $\sim 10^{-4}$. Incident beam size on the sample is typically $1.5 \mathrm{~mm} \times 1.5 \mathrm{~mm}$. The selected wavelength $\lambda=0.41068(1)$ $\AA$ (30 keV) was calibrated with Si standard NIST 640c (certified cell parameter $a=5.4311946$ (92) $\AA$ ). One $\mathrm{mm}$ outer-diameter quartz capillaries were filled with sample powder, then sealed, mounted horizontally, and spun at $1000 \mathrm{rpm}$ during data collection to improve particle statistics. Data were collected in the $1^{\circ}<2 \theta<45^{\circ}$ range, in continuous motion $5^{\circ} / \mathrm{min}$, and rebinned in $2 \theta$ step of $0.003^{\circ}$. Data acquisition time was $30 \mathrm{~min}$ for each sample at room temperature (RT) to ensure good counting statistics. For in situ heating measurements, the capillaries were heated with a hot air blower mounted vertically, perpendicular to the capillary. Temperature was controlled by a thermocouple located in the hot air stream. The 

steps of $60 \mathrm{~K}$ from 353 to $1073 \mathrm{~K}$ (heating rate of $10 \mathrm{~K} / \mathrm{min}$ ) and again at room temperature after cooling.

\begin{tabular}{|c|c|c|c|c|c|c|c|c|}
\hline \multirow{2}{*}{$\begin{array}{l}\text { Samples } \\
\text { Name_nominal } \\
\text { composition } \\
\text { P=1GPa T=1273 K }\end{array}$} & \multirow{2}{*}{\begin{tabular}{l} 
Composition \\
\multicolumn{2}{c}{$\mathrm{EMP}^{2}$} \\
$\mathrm{MgCO}_{3}$ (mol. \\
$\%)$
\end{tabular}} & \multirow{2}{*}{$\begin{array}{l}\text { Proportion } \\
\text { Weight \% }\end{array}$} & \multirow{2}{*}{$\begin{array}{l}\text { Space } \\
\text { Group }\end{array}$} & \multicolumn{2}{|c|}{ Unit cell parameters } & \multicolumn{3}{|c|}{ Microstructural parameters } \\
\hline & & & & $a(\AA ̊)$ & $c(\AA ̊)$ & $\begin{array}{l}\text { FWHM }(10 \\
\text { 4) } 2 \theta\left(^{\circ}\right)\end{array}$ & $\begin{array}{c}\text { size }<L> \\
(\mu)\end{array}$ & $\begin{array}{c}\underset{<\varepsilon>10^{-3}}{\text { microstrain }} \\
\end{array}$ \\
\hline MgCc_2 & $0.66(0.05)$ & & R3C & $4.98708(9)$ & $17.05868(4)$ & 0.0076 & 0.911 & 0.053 \\
\hline MgCc_4 & $3.23(0.10)$ & & & $4.97620(1)$ & $17.00054(5)$ & 0.0066 & 1.008 & 0.144 \\
\hline MgCc_6 & $4.02(0.12)$ & & & $4.95942(2)$ & 16.92903(9) & 0.0074 & 0.874 & 0.188 \\
\hline MgCc_8 & $6.08(0.12)$ & & & $4.96344(1)$ & $16.94464(5)$ & 0.0141 & 0.822 & 0.138 \\
\hline MgCc_10 & $9.67(0.30)$ & & & $4.94726(2)$ & $16.86430(9)$ & 0.0089 & 0.930 & 0.370 \\
\hline MgCc_12 & $9.52(0.13)$ & & & $4.94731(1)$ & $16.86683(5)$ & 0.0085 & 1.083 & 0.186 \\
\hline MgCc_14-1 & $11.64(0.68)$ & & & $4.93507(1)$ & $16.80922(8)$ & 0.0107 & 1.346 & 0.226 \\
\hline MgCc_14-2 & $11.31(0.22)$ & & & $4.93805(1)$ & $16.82313(8)$ & 0.0108 & 0.957 & 0.291 \\
\hline MgCc_16 & $12.45(0.21)$ & & & $4.93596(1)$ & $16.80992(5)$ & 0.0071 & 0.952 & 0.224 \\
\hline MgCc_18 & $14.46(0.14)$ & & & $4.92730(1)$ & $16.76702(7)$ & 0.0073 & 1.023 & 0.117 \\
\hline MgCc_20 & $16.31(0.27)$ & & & $4.92161(2)$ & $16.73950(8)$ & 0.0080 & 0.886 & 0.163 \\
\hline MgCc_22 & $18.23(0.26)$ & & & $4.91308(1)$ & $16.69584(8)$ & 0.0092 & 0.925 & 0.140 \\
\hline MgCc_24 & $20.69(0.27)$ & & & $4.90156(1)$ & $16.63502(5)$ & 0.0078 & 1.305 & 0.188 \\
\hline MgCc_26 & $22.02(0.40)$ & & & $4.89639(1)$ & $16.60686(8)$ & 0.0103 & 1.011 & 0.158 \\
\hline \multirow[t]{3}{*}{ MgCc_28 } & $23.97(0.26)$ & 43 & & $4.88237(4)$ & $16.5271(2)$ & 0.0108 & & \\
\hline & & 36 & & $4.88655(5)$ & $16.5547(2)$ & 0.0163 & & \\
\hline & & 21 & & $4.89116(4)$ & $16.5811(2)$ & 0.0187 & & \\
\hline \multirow[t]{3}{*}{ MgCc_30 } & $25.69(0.22)$ & 28 & & $4.87987(5)$ & $16.5220(2)$ & $0.0151^{*}$ & & \\
\hline & & 42 & & $4.87732(5)$ & $16.5010(2)$ & $0.0151^{*}$ & & \\
\hline & & 30 & & $4.87428(5)$ & $16.4786(2)$ & $0.0151^{*}$ & & \\
\hline \multicolumn{9}{|l|}{$\mathrm{P}=1.5 \mathrm{GPa} T=1373 \mathrm{~K}$} \\
\hline \multirow[t]{4}{*}{ MgCc_35 } & $28.25(0.30)$ & 31 & & $4.87108(5)$ & $16.4689(2)$ & $0.0155^{*}$ & & \\
\hline & $33.26(0.23)$ & 29 & & $4.86668(6)$ & $16.4387(2)$ & $0.0155^{*}$ & & \\
\hline & & 21 & & $4.86117(6)$ & $16.4052(2)$ & $0.0155^{*}$ & & \\
\hline & & 18 & & $4.83564(3)$ & $16.26039(1)$ & 0.0978 & & \\
\hline \multirow[t]{3}{*}{ MgCc_40 } & $37.77(0.50)$ & 46 & & $4.84199(3)$ & $16.2942(1) 0$ & $0.0108^{*}$ & & \\
\hline & & 25 & & $4.83869(4)$ & $16.2677(2)$ & $0.0108^{*}$ & & \\
\hline & & 29 & & $4.83462(3)$ & $16.2427(1)$ & $0.0108^{*}$ & & \\
\hline \multirow[t]{3}{*}{ MgCc_45 } & $41.43(0.36)$ & 31 & & $4.82739(8)$ & $16.2045(3)$ & $0.0097^{*}$ & & \\
\hline & & 21 & & $4.82516(1)$ & $16.1833(5)$ & $0.0097^{*}$ & & \\
\hline & & 48 & & $4.82191(6)$ & $16.1633(3)$ & $0.0097^{*}$ & & \\
\hline MgCc_50 & $49.23(0.29)$ & & R3 & $4.80585(1)$ & $16.05064(5)$ & 0.0085 & 1.580 & 0.196 \\
\hline
\end{tabular}

Table 1 Refined unit cell parameters, microstructural parameters [FWHM broadening, size $<L>$ and microstrain $\langle\varepsilon>$ ] of synthetic magnesian calcites and dolomite. (wavelength of $\lambda=0.41068$ (1) $\AA$ (30 $\mathrm{keV})$ ) (standard deviation in brackets). ${ }^{*}$ broadening coefficients of the pseudo-Voigt profile function constrained to the same values. Composition measured by EMP (Perrin et al., 2016)

\section{HRXRPD Pattern Analysis}

\section{Cell parameters}

Both whole powder pattern and single peak analyses were performed with the Fullprof software suite (Rodriguez-Carvajal 1993). In the Rietveld refinements, the diffraction peak profiles were fitted with a pseudo-Voigt profile function and corrected for the asymmetry due to axial divergence (Rietveld 1969). All samples were refined in the rhombohedral system using the $R \overline{3} c$ space group for calcite, Mg-calcite and magnesite, and the $R \overline{3}$ space group for dolomite and Ca-dolomite. Starting atomic coordinates, cell parameters, and isotropic 
temperature factors of calcite and magnesite are taken from (Maslen et al. 1995) while those of dolomite and Mg-calcite are from (Althoff 1977). The atomic composition of each powder sample was determined by EMP with a mean value and a standard deviation. Consequently, (1) the random occupancy of $\mathrm{Ca}$ and $\mathrm{Mg}$ into octahedral sites for $\mathrm{Mg}$ calcite samples were not refined but constrained to the EMP composition, (2) the $\mathrm{CO}_{3}$ group was considered as a rigid structural unit. The $\mathrm{C}-\mathrm{O}$ bond length was previously found to be very close to $1.284 \AA$ for several carbonate phases, including magnesite and otavite (Reeder 1983 ; Zemann 1981). The $\mathrm{C}-\mathrm{O}$ bond length was fixed as a function of $\mathrm{Mg}$ content $\left(\mathrm{n}_{\mathrm{Mg}}\right)$, between the $\mathrm{C}-\mathrm{O}$ bond lengths in calcite $\left(\mathrm{n}_{\mathrm{Mg}}=0, \mathrm{~d}(\mathrm{C}-\mathrm{O})_{\text {calcite }}=1.2864 \AA\right)$ and in dolomite $\left(\mathrm{n}_{\mathrm{Mg}}=0.5, \mathrm{~d}(\mathrm{C}-\mathrm{O})_{\text {dolomite }}=1.2831 \AA\right.$ ). It was constrained according to the linear relation $\mathrm{d}(\mathrm{C}-\mathrm{O})_{\mathrm{MgCc}}=-0.000068 \times \mathrm{n}_{\mathrm{Mg}}+1.2864$ (with $\mathrm{n}_{\mathrm{Mg}}$ : mol.\% $\mathrm{MgCO}_{3}$ determined by EMP reported on Table 1 ). The background function, scale factors, unit-cell parameters, Gaussian and Lorentzian broadening coefficients of the pseudoVoigt profile function, and March-Dollase preferred orientation parameters were refined for each entire diffractogram. Atomic positions were refined only for OCN calcite, dolomite and magnesite. In the synthetic Mg calcites, where oxygen position and $\mathrm{Ca}$ and $\mathrm{Mg}$ occupations were constrained, typical agreement factors, $\chi^{2}, R_{\mathrm{p}}$, and $R_{\mathrm{wp}}$ ranged from 3 to $13,0.08$ to 0.10, and 0.12 to 0.15 , respectively.

\section{Long-range and short-range atom ordering}

The degree of order is of primary importance in the calcite-dolomite-magnesite system. As summarized by (Putnis 1992), the degree of order involves two different concepts.

Long-range order involves the occupancies of the sites averaged over the complete crystal. It is defined in terms of relative occupancy of non-equivalent sites. In the case of dolomite, the disordered state occurs on sites of two distinct layers, Ca layers labelled $\alpha$ and Mg layers labelled $\beta$. The degree of cation order is described by the order parameter $s$, defined as $s=$ $\left(\mathrm{n}_{\mathrm{Ca}, \alpha}-\mathrm{n}_{\mathrm{Ca}, \beta}\right) /\left(\mathrm{n}_{\mathrm{Ca}, \alpha}+\mathrm{n}_{\mathrm{Ca}, \beta}\right)$ where $\mathrm{n}_{\mathrm{Ca}, \alpha}$ and $\mathrm{n}_{\mathrm{Ca}, \beta}$ is the occupancy of Ca-type cations in Ca-type layers and Mg-type layers, respectively. The long-range order parameter equals 0 in the fully disordered state and 1 in the fully ordered state. Other equivalent formulations for the $s$ order parameter were found for stoichiometric dolomites: $s=-1+2 \times \mathrm{n}_{\mathrm{Ca}, \alpha}$ (Reeder and Wenk 1983) and for Ca-rich dolomite $s=\left(2 \times n_{C a, \alpha}-n_{C a, \beta}\right) /\left(2-n_{C a, \alpha}-n_{c a, \beta}\right)$ where $n_{c a, \alpha}$ and $n_{c a, \beta}$ are the occupancy of Ca-type cations in Ca-type layers and in Mg-type layers, respectively. (Reeder $\underline{2000})$.

When the occupancy of Ca-type cations could not be refined, it is usual to calculate the long range order parameter in dolomite structure from the intensity of $b$-type peaks. In the dolomite diffractograms, the periodic layer arrangement of the non-equivalent sites gives rise to $b$-type ordering peaks [( $\left.\left.\begin{array}{lll}1 & 0 & 1\end{array}\right),\left(\begin{array}{lll}0 & 1 & 5\end{array}\right),\left(\begin{array}{lll}0 & 2 & 1\end{array}\right)\right]$ characteristic of the $R \overline{3}$ space group (Goldsmith and Heard 1961; Reeder and Nakajima 1982; Deelman 1999). In this case, the longrange order parameter is related to the intensities of normal $\left(\begin{array}{ll}0 & 0\end{array}\right)$ and $b$-type $\left(\begin{array}{lll}0 & 1 & 5\end{array}\right)$ peaks, and defined as $\sqrt{\left(\mathrm{I}_{015} / \mathrm{I}_{006}\right)}$ ((Zucchini et al. 2012) and references therein).The order parameter $\sqrt{ }\left(\begin{array}{lllll}l_{0} & 1 & 5\end{array} / l_{0} \quad 0 \quad 6\right)$ was determined from diffraction patterns computed with Fullprof for 
stoichiometric dolomites (Supp. Mat. Fig. S1). From $n_{C a, \alpha}=1$ to $0, \sqrt{\left(l_{015} / l_{006}\right)}=0.0058 \times\left(n_{C a}\right)^{2}$ $+1.0621 \times n_{C a}+0.0335$ where $n_{C a}$ is the Ca occupancy at its normal site in the dolomite structure. The order parameter $\left.\sqrt{\left(l_{0}\right.} 1_{5} / l_{0} 0_{6}\right)$ varies almost linearly between 1.1 and 0 from fully ordered $\left(n_{C a}=1\right)$ to fully disordered $\left(n_{C a}=0\right)$ dolomite. In the present study, the linear

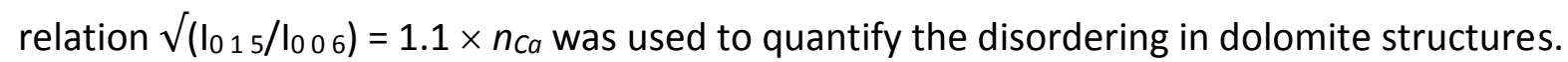
Short-range order was first introduced and theorized by Warren and Cowley (Warren et al. 1951; Cowley 1950, 1960). It involves the occupancies of the sites over a scale of a few $\AA$. It is defined by the probability that an atom is in the first coordination sphere surrounding an arbitrary atom relatively to the random probability. In the case of $\mathrm{Mg}$ calcite, the disordered state occurs on one set of equivalent cation $(\mathrm{Ca}, \mathrm{Mg})$ sites. The degree of short-range $\operatorname{order}(\alpha)$ is defined as $\alpha=1-P_{M g} / n_{M g}=1-P_{C a} / n_{C a}$ where $n_{M g}$ or $C_{a}$ is the $M g$ (or Ca) occupancy fraction, i.e. the random probability and $P_{M g}$ or ca the probability of $\mathrm{Mg}$ (or $\mathrm{Ca}$ ) atoms is within the first coordination sphere surrounding a central $\mathrm{Ca}$ (or $\mathrm{Mg}$ ) atom. In the random structure $\alpha=0$, while in the fully ordered structure $\alpha=1$. In the Rietveld analysis of the $\mathrm{Mg}$ calcite powder diffractograms, the substitution of $\mathrm{Mg}$ for Ca could not be refined, it was considered as fully random and disordered. All kinds of short-range order being not considered, led to lower agreement factors values. Besides, short-range order such as preferential occupancy of Ca and $\mathrm{Mg}$ into octahedral sites within domains would generate variations of intensities and nonuniform broadening of select families of reflections (Radha et al. 2007). In particular, (h k I) stacking faults would selectively broaden the peaks due to the $(h k l)$ family of reflections. The heat treatment of $\mathrm{Mg}$ calcites is expected to induce lattice parameter distortions and $\mathrm{Ca}$ and $\mathrm{Mg}$ re-ordering, but also change the average domain size and crystal lattice microstrain. For these specific microstructural characterizations, each single peak in the diffractogram was analyzed with the Winplotr program (Roisnel and Rodriguez-Carvajal 2001) and we used the Williamson-Hall plot method (Williamson and Hall 1953) in which the broadened peak is analyzed by a pseudo-Voigt function. The integrated intensity, coherent domain size $\langle L\rangle$ and average microstrain values $\langle\varepsilon\rangle$ are estimated from the refined profile width parameters. The coherent domain size was determined using the ( $\underline{\text { Scherrer } 1918})$ formula: $\langle L\rangle=\lambda / \beta \cos (\theta)$ where $\lambda, \beta$, and $\theta$ are the wavelength, integral breath, and Bragg angle, respectively (Scherrer 1918). The microstrain effect is the variance of the lattice spacing $(\Delta d / d)$ and the angular dependence of the form is defined as $\Delta d / d=\beta / \tan (\theta)$ (Stokes and Wilson 1942).

\section{Results and interpretations}

\section{HRXRPD characterization of magnesian calcite syntheses}

\section{Whole pattern analysis and cell parameters}

HRXRPD patterns of OCN calcite, OCN dolomite, and synthetic magnesian calcite MgCc24 $\left(\sim 20.7\right.$ mol\% $\mathrm{MgCO}_{3}$ ) are shown in Fig. 2. Note the narrowness of the peaks in the synthesized 
materials. No phase other than $\mathrm{Mg}$ calcite and/or dolomite was detected. No indication of extended basal cation stacking order such as $b$-type ordering reflections characteristic of the $(R \overline{3})$ ordered structure of dolomite was found in the synthetic carbonates in the range 2-45 mol\% $\mathrm{MgCO}_{3} . \mathrm{MgCc} 0$ with $49.2 \mathrm{~mol} \% \mathrm{MgCO}_{3}$ is the only synthetic sample with this type of ordering reflections. ( $\left(\begin{array}{lll}1 & 0 & 4\end{array}\right)$ peaks of OCN calcite, OCN dolomite and synthetic samples in the range 2-50 mol\% $\mathrm{MgCO}_{3}$ are shown in Fig. 3. The plots of the $\left(\begin{array}{lll}3 & 0 & 0\end{array}\right)$ and $\left(\begin{array}{lll}0 & 0 & 12\end{array}\right)$ peaks (distinctive $a$ and $c$ basal reflections, respectively) are provided as supplementary materials (Supp. Mat. Fig. S2). The three figures show the same general features and allow identifying two groups of syntheses: a first group comprising the $\mathrm{MgCc} 2$ to $\mathrm{MgCc} 26$ samples is characterized by narrow and symmetric peaks, a second group from MgCc28 to MgCc45 displays largely broadened and asymmetric peaks. The two groups will be referred to as low and high-Mg synthetic calcites, respectively. Diffractograms of the high-Mg synthetic calcite group can be analyzed in different ways: the peak broadening corresponds to a distribution curve of single phase $\mathrm{Mg}$ calcites with either 1) different Mg compositions, 2) different sizes and microdistortions ( $\mathrm{Ca} / \mathrm{Mg}$ disordering), or 3) different $\mathrm{Mg}$ compositions, sizes or microdistortions ( $\mathrm{Ca} / \mathrm{Mg}$ disordering). Table 1 reports the Rietveld refinement results of the simplest model involving three or four calcites with different compositions (and thus different cell parameters) and similar peak broadening. The origin of peak broadening will be discussed below. Refined unit cell parameters, microstructural parameters (FWHM broadening, size $\langle\mathrm{L}\rangle$ and microstrain $\langle\varepsilon>$ ) for, synthetic Mg calcites, synthetic dolomite and OCN crystals are given in Tables 1 and 2. Unit-cell parameters and volumes obtained for all synthetic samples are shown as a function of their Mg contents in Fig. 4. For the high-Mg synthetic calcites, values of the three phases used in the refinement are plotted in the diagram. The $a$ and $V$ parameters show a small negative deviation from the Cc-Dol straight line, whereas the $c$ parameter displays almost no deviation. These parameters can be fit with a second degree polynomial with $\mathrm{R}^{2}>0.995$ :

$$
\begin{aligned}
& \mathrm{a}(\AA)=4.9897-0.4747 \times\left(\mathrm{X}_{\mathrm{Mg}}\right)+0.2037 \times\left(\mathrm{X}_{\mathrm{Mg}}\right)^{2} \\
& \mathrm{c}(\AA)=17.0643-2.1221 \times\left(\mathrm{X}_{\mathrm{Mg}}\right)+0.0646 \times\left(\mathrm{X}_{\mathrm{Mg}}\right)^{2} \\
& \mathrm{~V}\left(\AA^{3}\right)=367.9028-114.8121 \times\left(\mathrm{X}_{\mathrm{Mg}}\right)+38.4623 \times\left(\mathrm{X}_{\mathrm{Mg}}\right)^{2}
\end{aligned}
$$

( $\mathrm{X}_{\mathrm{Mg}}$ : mole fraction of $\mathrm{MgCO}_{3}$ in the carbonate).

The fitting curves are shown in Fig.4. As stated by (Reeder 1983), $d_{(104)}$ has long been used to determine the $\mathrm{Mg}$ content of rhombohedral carbonates. In the present study the following relationship is determined:

$$
d\left(\begin{array}{lll}
1 & 0 & 4
\end{array}\right)(\AA)=-0.003032 \times\left(X_{M g}\right)+3.033503\left(R^{2}=0.994\right)
$$

It should be noted that $\mathrm{d}_{\left(10_{4}\right)}$ does not provide a unique description of the cell while lattice parameters do, and thus cell parameters should be preferred to determine $\mathrm{Mg}$ contents in $\mathrm{Ca}$ Mg carbonates (Reeder 1983). For natural carbonates (including biominerals) that may 
contain significant amounts of other components such as $\mathrm{Fe}, \mathrm{Mn}, \mathrm{Sr}, \mathrm{S}$, organic matrix, etc., direct measurements of compositions (by EMP for instance) should be preferred.

Note again that the substitution of $\mathrm{Mg}$ for $\mathrm{Ca}$ in $\mathrm{Mg}$-calcite has been considered as fully random and disordered in this analysis of the entire diffractograms. A more precise structural model that would take into account preferential occupancy of $\mathrm{Ca}$ and $\mathrm{Mg}$ into octahedral sites within domains, would possibly lead to better agreement-factor values. However in the present state of our knowledge, too many variables remain undetermined to allow this type of modelling with reasonable degree of confidence.

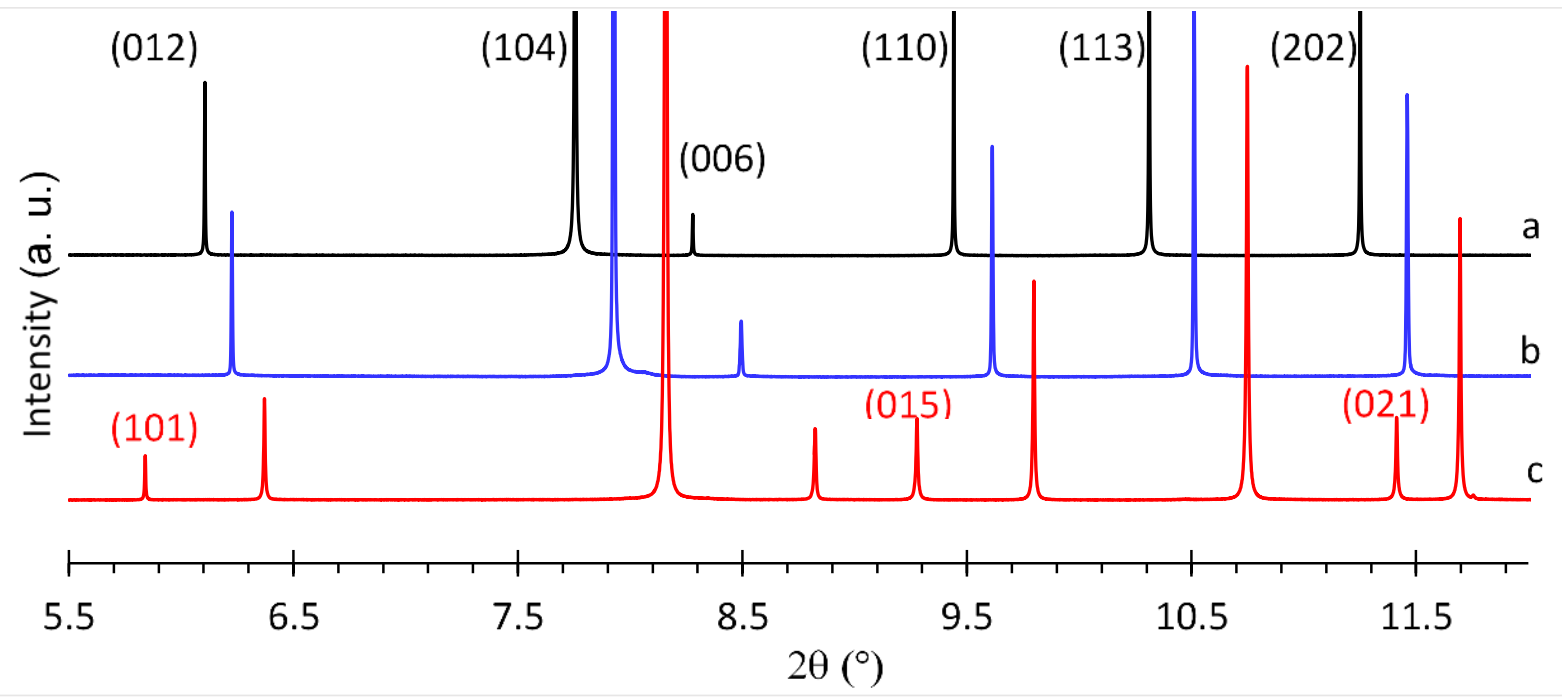

Fig. 2 HRXRPD patterns of (a) OCN calcite (black), (b) synthetic magnesian calcite MgCc24 (blue) and (c) OCN dolomite (red) [wavelength of $\lambda=0.41068(1) \AA(30 \mathrm{keV})$ ]. Bragg peaks in the range 5.5 to $12^{\circ}$ (20). $R \overline{3} c$ space group reflections in black, and $R \overline{3}$ space group $b$-type ordering reflections in red

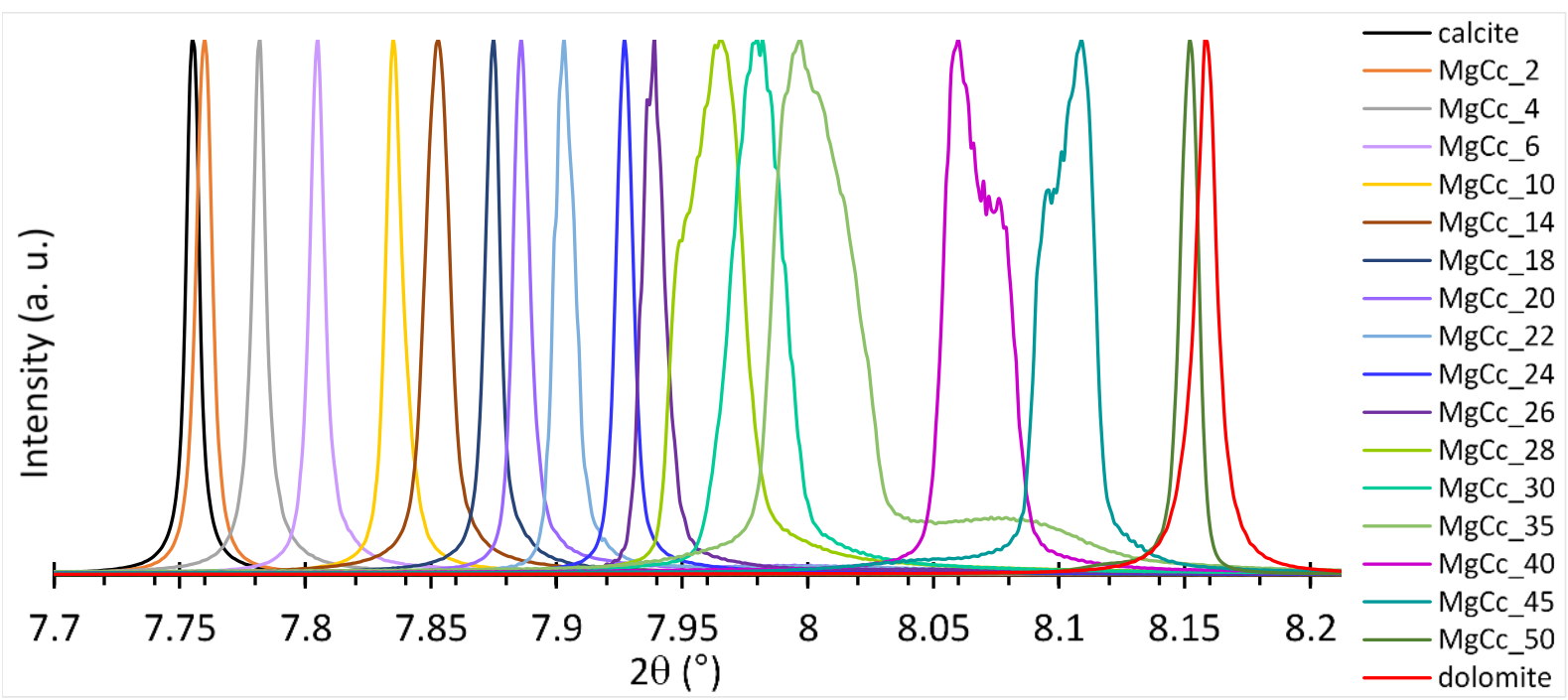
$\mathrm{MgCc} 45)$, synthetic MgCc50 dolomite and OCN dolomite (red) [wavelength of $\lambda=0.41068(1) \AA(30 \mathrm{keV})$ ] 

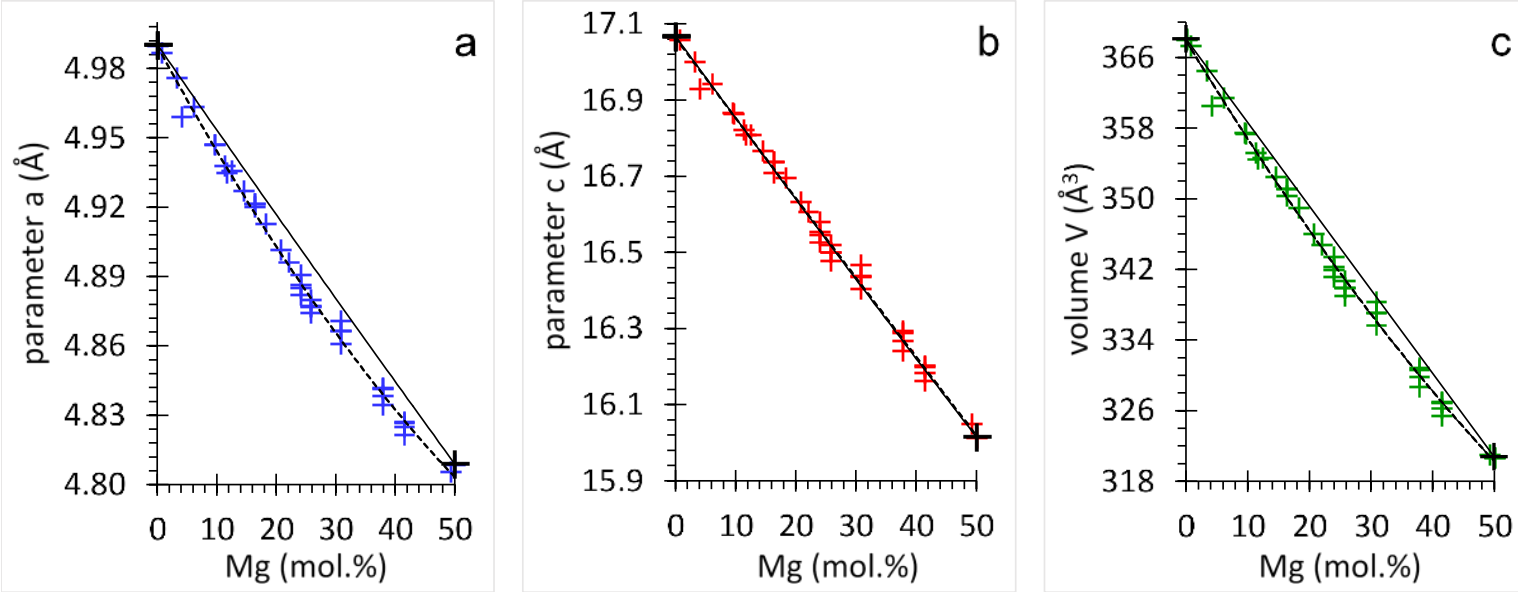

309

310

311

312

313

314

315

\begin{tabular}{|l|r|r|r|}
\hline \multicolumn{1}{|c|}{ Samples } & \multicolumn{1}{c|}{ Calcite } & \multicolumn{1}{c|}{ Dolomite } & \multicolumn{1}{c|}{ Magnesite } \\
\hline Unit cell parameters & \multicolumn{1}{|c|}{$\begin{array}{l}\text { Space } \\
\text { Group R3c }\end{array}$} & $\begin{array}{l}\text { Space } \\
\text { Group R3 }\end{array}$ & \multicolumn{1}{l}{$\begin{array}{l}\text { Space } \\
\text { Group R3c }\end{array}$} \\
\hline a $(\AA)$ & $4.98899(3)$ & $4.80892(1)$ & $4.63491(1)$ \\
\hline c $(\AA)$ & $17.05813(2)$ & $16.01536(5)$ & $15.02125(5)$ \\
\hline FWHM $(104) 2 \theta\left(^{\circ}\right)$ & 0.0072 & 0.0091 & 0.0104 \\
\hline size $<\mathrm{L}>(\mu)$ & 0.541 & 1.156 & 0.717 \\
\hline microstrain $<\varepsilon>10^{-3}$ & 0.197 & 0.144 & 0.129 \\
\hline Conventional Rietveld R-factors & \multicolumn{3}{|c|}{} \\
\hline Rp \% & 11.10 & 11.80 & 9.81 \\
\hline Rwp \% & 15.30 & 18.60 & 13.3 \\
\hline Rexp \% & 12.61 & 9.39 & 5.91 \\
\hline$\chi^{2}$ & 1.47 & 3.92 & 5.06 \\
\hline
\end{tabular}

Table 2 Refined unit cell parameters, microstructural parameters (FWHM broadening, size $<\mathrm{L}>$ and microstrain $\langle\varepsilon>$ ) and conventional Rietveld R-factors for OCN calcite, dolomite, and magnesite [wavelength of $\lambda=0.41068(1) \AA(30 \mathrm{keV})$ ] (Standard deviation in brackets)

Fig. 4 Unit cell parameters and volume as function of Mg composition for OCN calcite, OCN dolomite (black plus) and for synthetic carbonate (blue, red and green plus). Dashed line is the quadratic leastsquare adjustment as discussed in the text. Solid line is the straight line between OCN calcite and OCN dolomite

\section{Single peak analysis and microstructural parameters}

Short-range disorder in $\mathrm{Mg}$ calcites associated with the shift in position of atoms and distortion of octahedral sites must generate variations of $(h k l) l=e v e n$ intensities because of large differences in X-ray scattering factors between calcium and magnesium atoms. Misorientation of carbonate ions must generate variations of $(h k l) l=$ odd intensities. As far as long-range order is concerned, the spatial extent and the structural nature of long range order in $\mathrm{Mg}$ calcites domain must generate non-uniform widening of some families of reflections. Below, both intensities and FWHM of the diffraction peaks are analyzed in order to characterize both the structural short- and/or long-range order and the length of structural coherence. 
Intensities of several first $(h \mathrm{kl} /$ ) peaks for even and odd (/)s are shown in Figs. 5a and 5b as a function of $\mathrm{Mg}$ contents, and they are compared to those calculated from randomly disordered $\mathrm{Mg}$ calcite structure. Intensities of all $(h \mathrm{k} /)$ peaks vary linearly as a function of $\mathrm{Mg}$ content. No particular $(h k l)$ intensity variation as a function of $\mathrm{Mg}$ content is observed. Some of them increase while others decrease. The deviations from linearity $(S D=0.10)$ are small and not correlated to $\mathrm{Mg}$ content and $(h k l)$ families. A small deviation could be attributed to random distribution of structural distortions such as locally restricted cation ordering and anion positional disorder (off-planar tilting of the $\mathrm{CO}_{3}$ groups) (Althoff 1977; Paquette and Reeder 1990). In the present case, the deviations are erratic and prevent refining a better structural model with confidence.
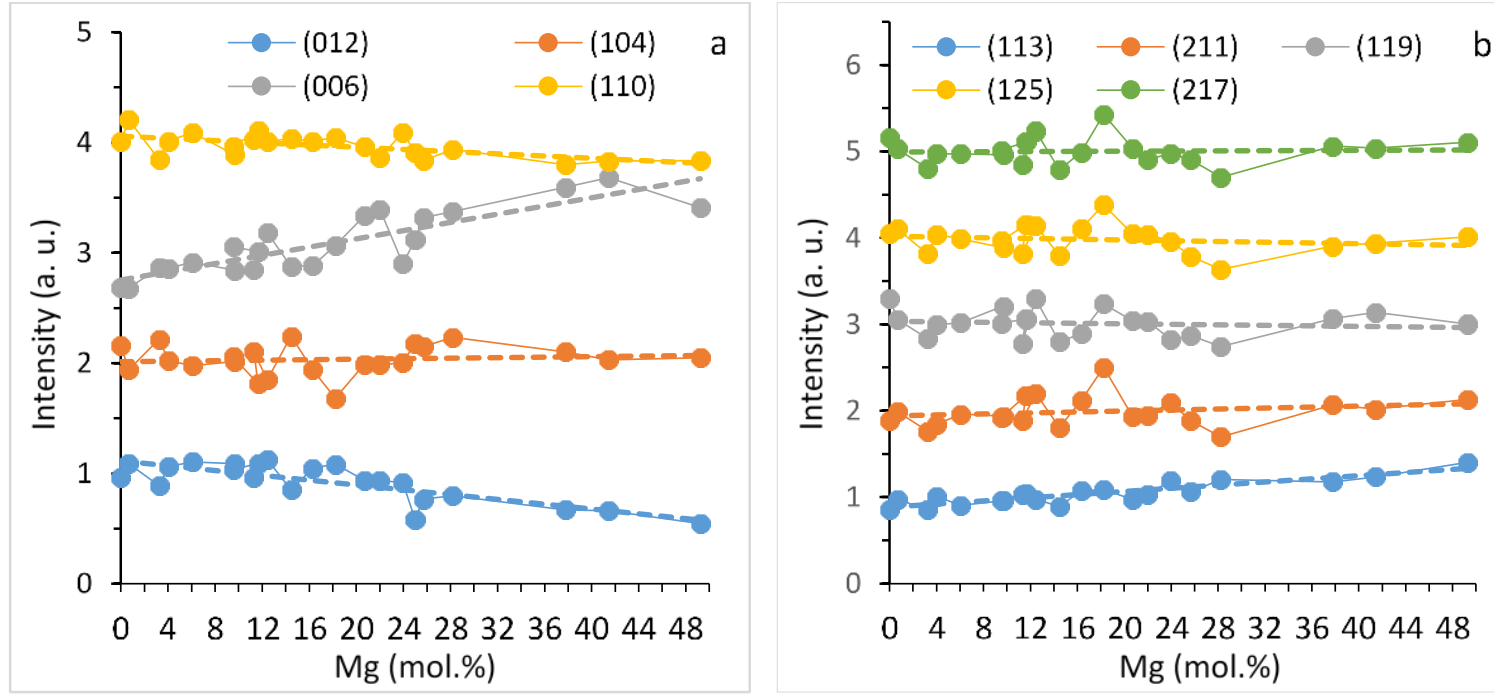

Fig. 5 Observed intensities of ( $h k h$ peaks a) l=even (distortion of octahedral sites); b) l=odd (misorientation of $\mathrm{CO}_{3}$ groups) of synthetic carbonates as a function of $\mathrm{Mg}$ composition for synthetic carbonates (filled circles). The dashed line represents the intensities calculated for ideally disordered Mg calcites. All observed and calculated intensity are normalized to the same scale factor. Intensity axis is offset for each $(h k l)$ for clarity

Concerning the FWHM, it has been mentioned earlier that two groups can be defined on the basis of peak FWHM differences, as observed in Fig. 3 (see also Supp. Mat. Fig. S2). In the low$\mathrm{Mg}$ synthetic calcites (0-26 mol. \% $\left.\mathrm{MgCO}_{3}\right)$, the FWHM variation of each $(h k l)$ peak as a function of $\mathrm{Mg}$ content is small (usually less than $0.3 \%$ ) (SD in Fig. 6). The largest values and variations are for $(h k l)$ peaks with large $/$ values such as $\left(\begin{array}{lll}1 & 0 & 10\end{array}\right)\left(\begin{array}{lll}2 & 0 & 8\end{array}\right)\left(\begin{array}{lll}0 & 0 & 12\end{array}\right)\left(\begin{array}{lll}0 & 2 & 10\end{array}\right)$ and (1 112$)$. The $(h k l)$ families with large / values are sensitive to local basal stacking disorder, but here again we must remain cautious as differences with variations observed in OCN calcite are small (Fig. 6). The structural distortions determined with the Williamson-Hall plot method are given in Table 1. The mean coherent domain size $\langle\mathrm{L}\rangle[1.0 \mu \mathrm{m}(\mathrm{SD}=0.2)]$ is similar to OCN calcite (Fig. 7a). However, the average microstrain $\langle\varepsilon\rangle=2 \times 10^{-4}\left(S D=0.7 \times 10^{-4}\right)$, that is 4 times higher 
than in OCN calcite (Fig. 7b), could be related to the random distribution of structural distortions leading to small intensity deviations described above.

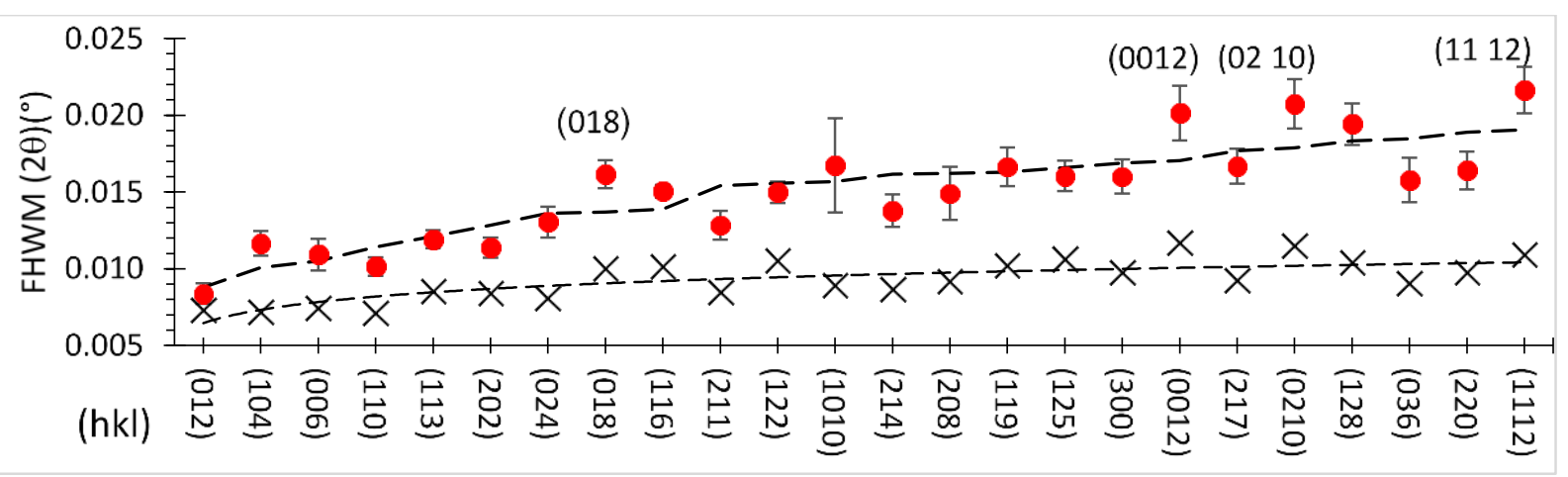

Fig. 6 FWHM of OCN calcite ( $h k I$ peaks (black crosses). Mean FWHM of $(h k I$ peaks of 13 samples of synthetic low-Mg carbonates (MgCc2 to MgCc26) (red dots, vertical bars are standard deviations)
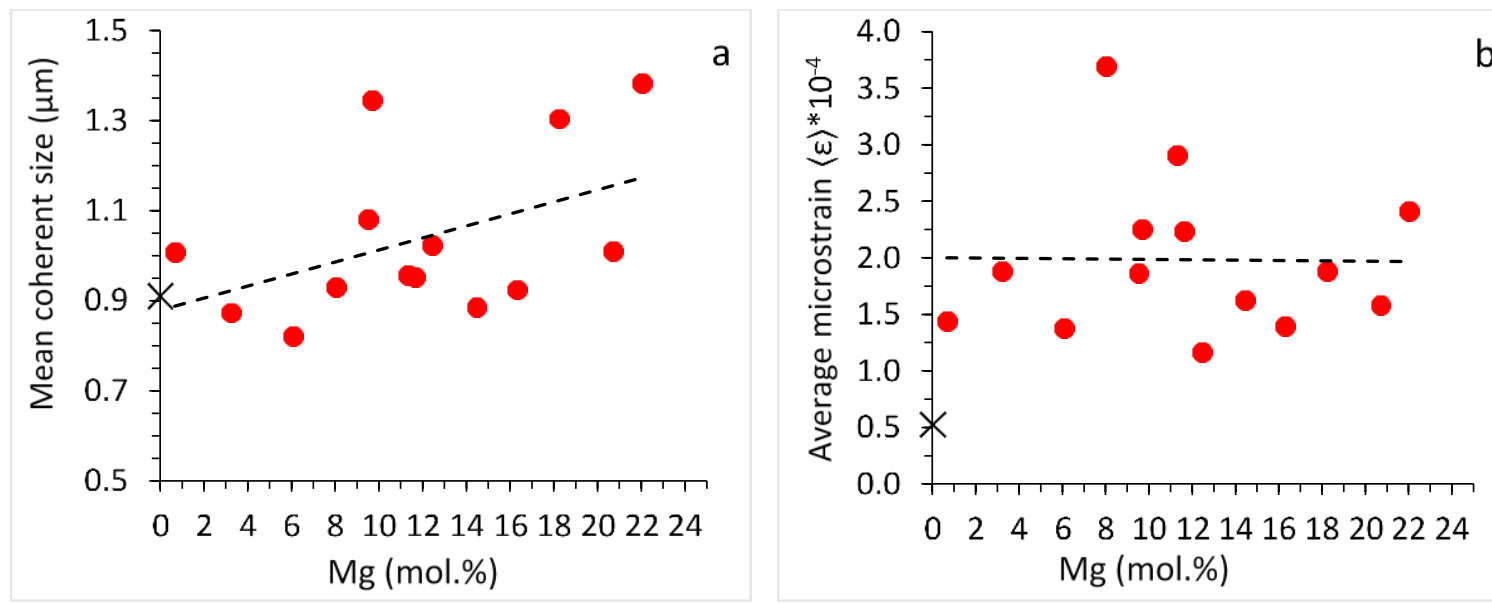

Fig. 7 a) Mean coherent domain size $\langle L\rangle$; b) average microstrain values $\langle\varepsilon\rangle$ calculated by the WilliamsonHall plot method for OCN calcite (black crosses) and for low-Mg synthetic carbonates (MgCc2 to $\mathrm{MgCc} 26)$ (red dots). Dashed lines are linear least-square fitting curves

In the case of high-Mg synthetic calcites, the FWHM of the diffraction peaks are three to four time larger than low-Mg calcites (Fig. 3, Supp. Mat. Fig. S2). In addition, the peaks are asymmetric whatever the $\mathrm{Mg}$ content, and in a similar way for each $(h k l)$ peak family. Thus, the FWHM broadening cannot be interpreted in terms of domain size and microstructural defects but rather in terms of coexistence of tiny domains with different compositions in a single crystal (Table 1). This interpretation will be developed in the discussion below. 
Special emphasis must be put on the MgCc50 sample that shows the characteristic superlattice peaks of dolomite. In this case and compared with OCN dolomite, no FWHM broadening of the $(h k l)$ peaks indicative of disordered stacking sequences is observed (Figs. 3 and 8 ). FWHM of the ( $\left.\begin{array}{lll}1 & 0 & 4\end{array}\right)$ peak (Fig. 3) and calculated size $\langle L\rangle$ and microstrain $\langle\varepsilon\rangle$ are similar to those of OCN dolomite (Tables 1 and 2). For OCN dolomite, the long-range cation order parameter $\sqrt{\left(\mathrm{I}_{015} / \mathrm{I}_{006}\right)}$ is equal to 1.07 whereas $\sqrt{ }\left(\mathrm{I}_{015} / \mathrm{I}_{006}\right)$ for $\mathrm{MgCc} 50$ dolomite equals 0.64 (as a reminder, $\sqrt{\left(\mathrm{I}_{0}{ }_{5} / \mathrm{I}_{0}{ }_{6}\right)}$ of a fully ordered dolomite equals 1.1$)$. Thus, OCN dolomite is almost fully ordered with only $3 \%$ cation disorder, while the synthetic MgCc50 dolomite is characterized by $36 \%$ cation disorder. Such high disordered dolomite is expected at $1373 \mathrm{~K}$ since the critical temperature for the transition between long-range ordered and disordered dolomite has been located close to $1473 \mathrm{~K}$ (Goldsmith and Heard 1961). A similar degree of disorder $(s=0.75)$ is reported by (Reeder and Wenk 1983) in a natural dolomite, thermally treated at $T=1373 \mathrm{~K}$ and $P=1.1 \mathrm{GPa}$.

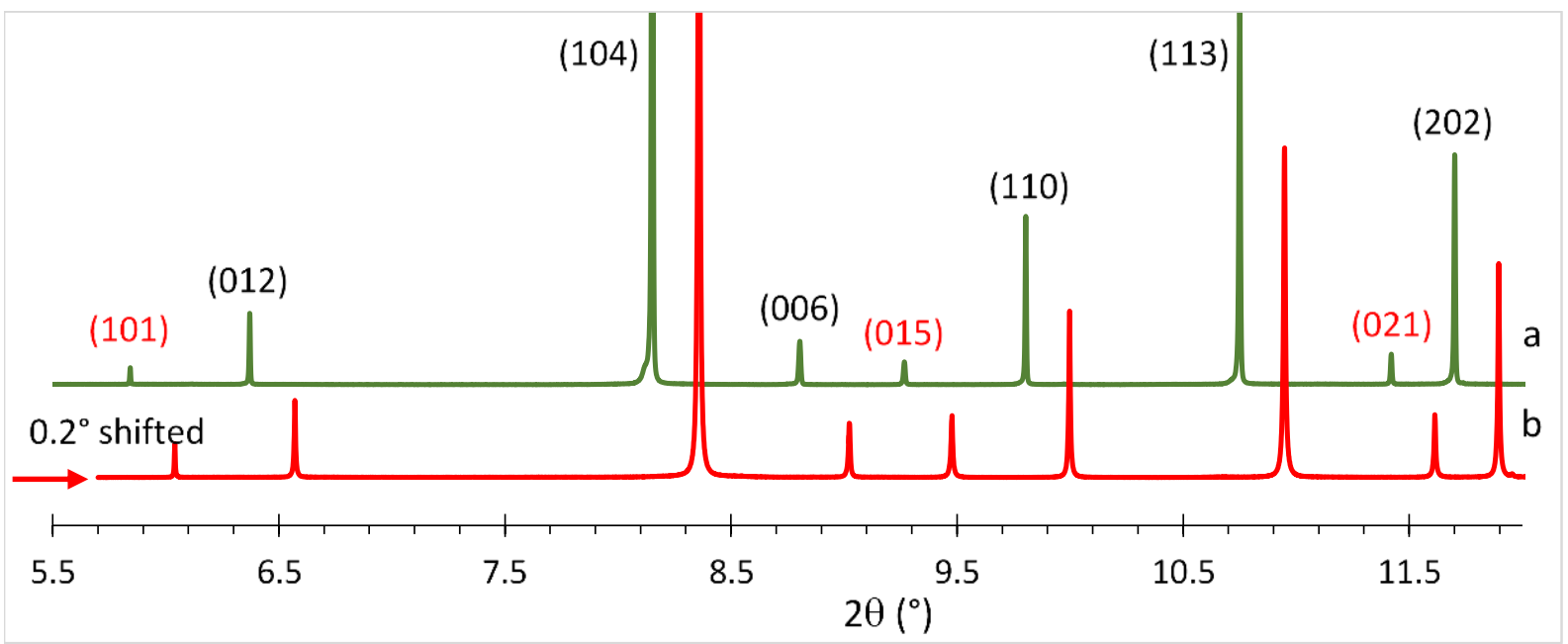

Fig. 8 HRXRPD diffractograms of the OCN and synthetic MgCc50 dolomites (in red and green, respectively) (wavelength of $\lambda=0.41068(1) \AA(30 \mathrm{keV})$ ). Bragg peaks in the $2 \theta$ range from 5.5 to $12\left(^{\circ}\right)$. Normal reflections and $b$-type ordering reflections for space group $R \overline{3}$ are noted in black and red, respectively. The red (OCN dolomite) has been shifted in $2 \theta$ for clarity

\section{Thermally processed magnesian calcite syntheses}

OCN dolomite, and the synthetic MgCc24, MgCc40, and MgCc50 samples have been thermally processed following the step-mode heating process previously used for OCN calcite and MgCc10 (Floquet et al. 2015). In this previous work, no phase decomposition of OCN calcite or MgCc10 was observed until $1073 \mathrm{~K}$. As expected, the calcite unit cell showed contrasting thermal contraction and expansion for the $a$ and $c$ parameters, respectively. For $\mathrm{Mg}$ calcite MgCc10, the a cell parameter decreased until $673 \mathrm{~K}$, then increased, while the $c$ parameter expanded monotonically all along the temperature range. Figs. 9 and 10 display the XRD patterns collected at different temperatures for the MgCc24, MgCc40 and MgCc50 samples. 


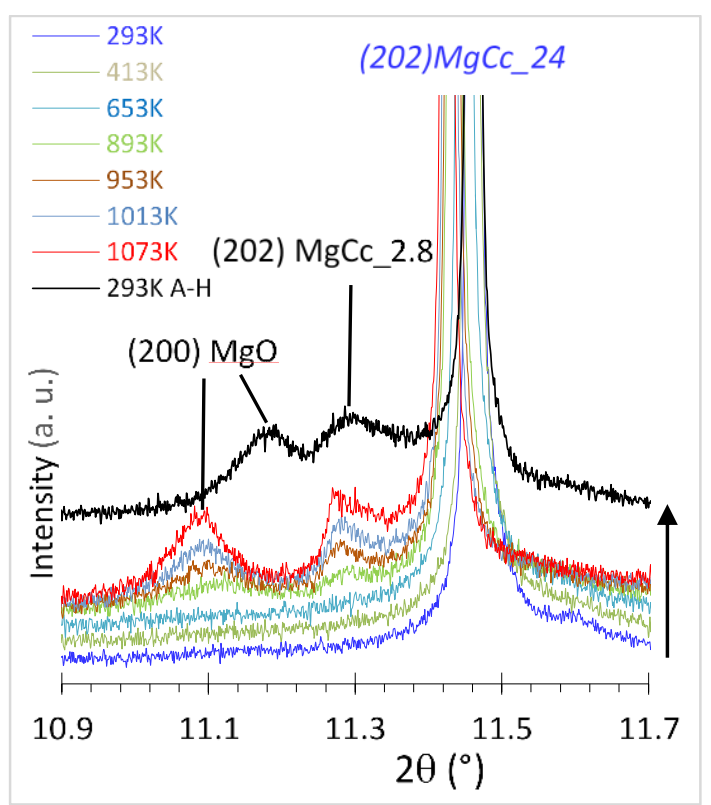

Fig. 9 - Selected HRXRPD diffractograms in the 10.9 $-11.72 \theta\left(^{\circ}\right)$ range of the synthetic MgCc24 sample recorded from $R T$ to $T=1073 \mathrm{~K}$ and then back to $R T$ after heating (293 K A-H), showing (1) the (2 02 2) peaks of untransformed magnesian calcite ( $\mathrm{T}$ in the range $\mathrm{RT}-653 \mathrm{~K}$, indexes in italics) and partially decomposed product (at $\mathrm{T}>653 \mathrm{~K}$ ), and (2) the (2 00 ) peak of $\mathrm{MgO}$ resulting from partial decomposition (above $653 \mathrm{~K}$ ). The black diffractogram collected at RT after annealing is shifted in intensity for clarity (black vertical arrow). [wavelength of $\lambda=0.41068(1) \AA(30 \mathrm{keV})$ ]
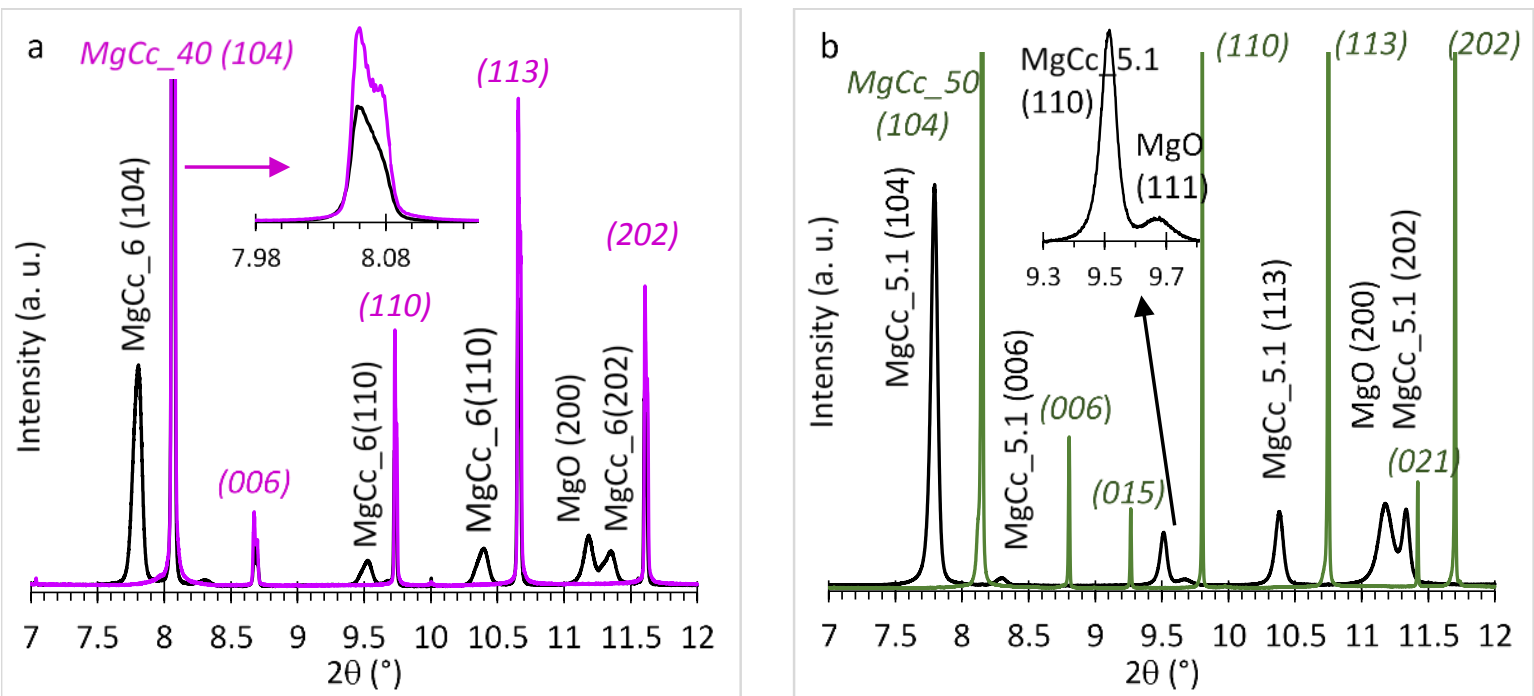

Fig. 10 - a) HRXRPD patterns of synthetic MgCc40 recorded at RT (purple line, indexes in italics) and after annealing back to RT (black line). The original material (high-Mg calcite) is partially transformed into low-Mg calcite ( 6.0 mol. \% $\left.\mathrm{MgCO}_{3}\right)$ and $\mathrm{MgO}$; b) HRXRPD patterns of the synthetic dolomite $\mathrm{MgCc50}$ recorded at RT before thermal processing (green line, and indexes in italics) and at RT after annealing at $1073 \mathrm{~K}$ (black line). The original dolomite has been totally transformed into low $\mathrm{Mg}$ calcite with $\sim 5.1 \mathrm{~mol} . \% \mathrm{MgCO}_{3}$ and $\mathrm{MgO}$. [wavelength of $\lambda=0.41068(1) \AA(30 \mathrm{keV})$ ] 
Refined unit cell parameters and FWHM of $\left(\begin{array}{lll}1 & 0 & 4\end{array}\right)$ peaks of the samples as a function of temperature are given in Table 3 and as supplementary data (Supp. Mat. Tables S1 and S2). Partial decomposition (PD) [or 'half decomposition' according to many authors (e.g. (Valverde et al. 2015) and refs therein)] meaning that an original magnesian calcite progressively decomposes at high temperature into a less magnesian calcite plus $\mathrm{MgO}$, is observed for the three samples. The beginning temperature of partial decomposition ( $\left.T_{\mathrm{PD}}\right)$, decreases as the $\mathrm{Mg}$ content increases. For instance, $\mathrm{MgCc} 24, \mathrm{MgCc} 40, \mathrm{MgCc50}$ start forming low Mg calcite ( 2.8 to 6 mol\% $\mathrm{MgCO}_{3}$ ) and periclase at $T_{\mathrm{PD}}$ of about $893 \mathrm{~K}, 833 \mathrm{~K}$ and $773 \mathrm{~K}$, respectively (Figs. 9 and 10, Table 3). After annealing at $1073 \mathrm{~K}$ for $20 \mathrm{~min}$ followed by cooling down to RT, MgCc24 and MgCc40 are only partially decomposed, whereas the dolomite sample (MgCc50) is completely transformed into low $\mathrm{Mg}$ calcite ( $5.1 \mathrm{~mol}$ \% $\mathrm{MgCO}_{3}$ ) and $\mathrm{MgO}$. These observations are in great part in agreement with those of (Reeder and Markgraf 1986) who observed the beginning of dolomite decomposition at $\sim 973 \mathrm{~K}$ and total transformation into $\mathrm{Mg}$ calcite at $\sim 1023 \mathrm{~K}$ in partial $\mathrm{CO}_{2}$ pressure. The average sizes of newly formed $\mathrm{Mg}$ calcite and periclase determined from the FWHM of the peaks using the Scherrer method, $\angle L>\sim 80$ and $\sim 50 \mathrm{~nm}$, respectively, are similar to those reported from XRD analysis of the thermal decomposition of dolomite. (Hashimoto et al. 1980; Rodriguez-Navarro et al. 2012)

428

\begin{tabular}{|c|c|c|c|c|c|c|c|}
\hline & \multirow{2}{*}{$\begin{array}{c}\text { Partial } \\
\text { decomposition } \\
\text { temperature } \\
\text { (K) }\end{array}$} & \multicolumn{2}{|c|}{$\begin{array}{c}\text { Partial decomposition } \\
\text { products at RT }\end{array}$} & \multirow[t]{2}{*}{$\begin{array}{l}\text { Quantity } \\
\text { Weight \% }\end{array}$} & \multicolumn{2}{|c|}{ Unit cell parameters } & \multirow{2}{*}{$\frac{\text { FWHM }\left(\begin{array}{lll}1 & 0 & 4\end{array}\right)}{2 \theta\left({ }^{\circ}\right)}$} \\
\hline & & Formula & $\begin{array}{l}\text { Mg mol. } \% \\
\text { (1) }\end{array}$ & & $\mathrm{a}(\AA ̊)$ & $c(\AA ̊)$ & \\
\hline \multirow[t]{3}{*}{$\mathrm{MgCc} 24$} & \multirow[t]{3}{*}{893} & MgCc24-ah & 20.5 & 90.8 & $4.90154(1)$ & $16.6345(5)$ & 0.008 \\
\hline & & $\mathrm{MgCc}$ & 2.8 & 8.4 & $4.97000(1)$ & $17.0500(5)$ & \\
\hline & & $\mathrm{MgO}$ & & 0.8 & $4.2523(9)$ & & \\
\hline \multirow[t]{4}{*}{$\mathrm{MgCc} 40$} & \multirow[t]{4}{*}{833} & MgCc40-1-ah & 37.2 & 38.3 & $4.84346(4)$ & $16.2870(2)$ & 0.014 \\
\hline & & MgCc40-2-ah & 39.0 & 21.5 & $4.83823(4)$ & $16.2435(2)$ & 0.020 \\
\hline & & $\mathrm{MgCc}$ & 6.0 & 32.8 & $4.9500(1)$ & $17.0172(5)$ & \\
\hline & & $\mathrm{MgO}$ & & 7.4 & $4.2144(7)$ & & \\
\hline \multirow[t]{3}{*}{$\mathrm{MgCc50}$} & \multirow[t]{3}{*}{773} & $\mathrm{MgCc}$ & 5.1 & 73.9 & $4.95435(1)$ & $17.0359(5)$ & 0.059 \\
\hline & & & & & & & $<L>=80 \mathrm{~nm}$ \\
\hline & & $\mathrm{MgO}$ & & 26.1 & $4.2164(2)$ & & $\begin{array}{c}0.130 \\
\langle>=55 \mathrm{~nm}\end{array}$ \\
\hline
\end{tabular}

429

430

431

432

433

434

435

436

437

438

439

440

Table 3 Partial decomposition temperature, composition, structural parameters (refined unit cell parameters) and microstructural parameters (FWHM broadening, size $<L>$ ) of the decomposition products measured at RT after final step of annealing at $1073 \mathrm{~K}$ for MgCc24, MgCc40 and MgCc50. [wavelength of $\lambda=0.41068(1) \AA$ (30 keV)]. (ah: after heating)

(1) $\mathrm{Mg}$ contents calculated from the present study calibration curve that links the $\mathrm{V}$ parameter to the $\mathrm{Mg}$ content of synthetic Mg calcites (Fig. 4c)

\section{Variation of cell parameters with temperature}

The variations of the unit cell parameters of MgCc24, MgCc40 and MgCc50 in the range RT$1073 \mathrm{~K}$ are plotted in Fig. 11. Note that in the experiments undergoing partial decomposition, cell parameters were determined on the remaining magnesian calcite that did not undergo 


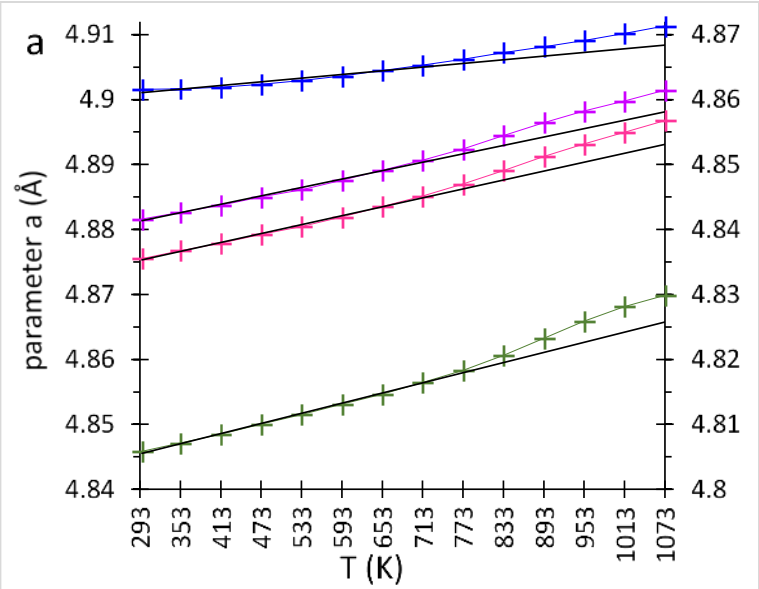
synthetic dolomite $\left(T_{\text {dif }} \sim T_{\mathrm{PD}}\right)$.

partial decomposition. The unit cell shows a thermal expansion for both $a$ and $c$ parameters, even for $\mathrm{MgCc} 24$ with $20.7 \mathrm{~mol} \% \mathrm{MgCO}_{3}$. The temperature dependence of $a, c$ and $V$ is not linear over the entire temperature range, as best observed in the $c / a$ vs T plot (Supp. Mat. Fig. S3). Note that for MgCc40, a model with two Mg compositions (MgCc40-1 and MgCc40-2) has been used to refine the diffractogram, hence two curves are plotted in Figs. 11, Supp. Mat. Fig. S3 for the MgCc40 experiment. The deviation from a linear expansion is positive for $a$, but negative for $c$, except for $\mathrm{MgCc} 24$ that shows a linear expansion for $c$. The $c / a$ ratio of the unit cell deviates negatively from linearity at $T_{\text {dif }}$ of about $653 \mathrm{~K}, 673 \mathrm{~K}$ and $773 \mathrm{~K}$ for $\mathrm{MgCc} 24$, MgCc40 and MgCc50, respectively (Supp. Mat. Fig. S3). A similar deviation occurs at $\sim 673 \mathrm{~K}$ for $\mathrm{MgCc10}$ due to the parabolic expansion of the a parameter (Floquet et al. 2015). The change of the thermal unit cell deformation starts at a temperature ( $\left.T_{\text {dif }}\right)$ lower than the beginning of partial decomposition ( $\left.T_{\mathrm{PD}}\right)$ for $\mathrm{Mg}$ calcite, and at the same temperature for the

455

456

457

458

459

460

461

462

463

464

465

466

467

468

469

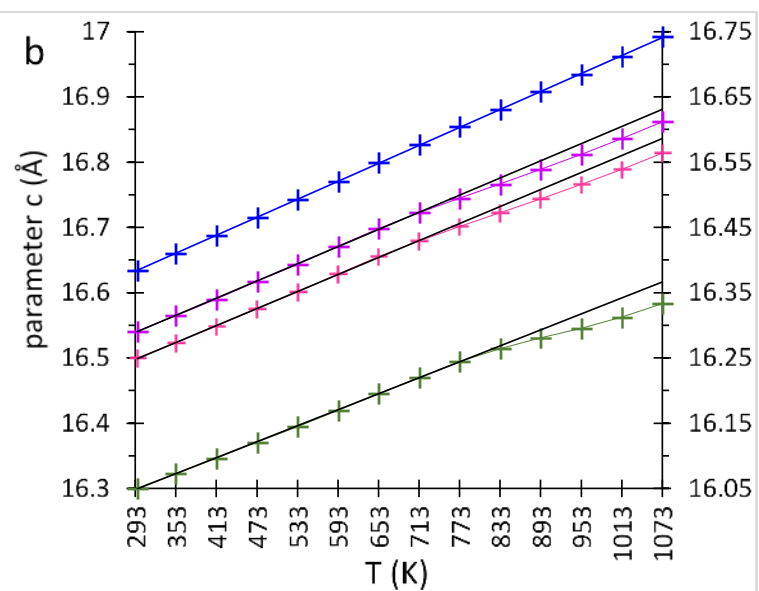

Fig. 11 Thermal expansion of the unit cell parameters a) a parameter; b) $c$ parameter for synthetic MgCc24 (blue), MgCc40-1 and 2 (purple and pink) and MgCc50 (green), respectively

Above, two important temperatures are put forward: $T_{\text {dif }}$ which is the temperature of the beginning of deviation from a linear expansion of the $a, c$ (and $V$ ) parameter, and TPD the temperature of beginning of partial half decomposition of $\mathrm{Mg}$ calcites. The physical meaning of $T_{\mathrm{PD}}$ is straightforward, as discussed above, while that of $T_{\text {dif }}$ is not. On the basis of Raman characterizations, it has been argued that significant short-range Ca-Mg cation order is present in magnesian calcites that crystallized at $1273 \mathrm{~K}$ or $1373 \mathrm{~K}$. Three reasons have been invoked: (1) the wavenumbers of magnesian calcites are close to the calcite-dolomite line (and not to calcite-magnesite), (2) the FWHM of the T, L, and $v 4$ modes reach a maximum around $30 \pm 5 \mathrm{~mol} \% \mathrm{MgCO}_{3}$, and (3) the active mode $\left(v_{2}, \mathrm{~A} 2 \mathrm{~g}\right)$ in dolomite at $880 \mathrm{~cm}^{-1}$ is observed in high-magnesian calcites above $\sim 10$ mol\% $\mathrm{MgCO}_{3}$ (Perrin et al. 2016). It should be noted also that short-range order greatly depends on temperature, it increases as temperature decreases. Thus, $T_{\text {dif }}$ is interpreted as the temperature at which re-ordering (by diffusion) of calcium and magnesium atoms is activated to reach a more stable short-range 
ordering configuration. For the studied $\mathrm{Mg}$ calcite samples, $T_{\text {dif }}$ is lower than $\mathrm{TPD}_{\mathrm{P}}$ and the two processes are expected to produce effects on Bragg peaks as a function of temperature, in addition to the thermal vibrational effect reflected in the Debye-Waller factors. Actually, the partial decomposition is mainly related to the decrease of all $(h k l)$ peak intensities. In contrast, a short-range re-ordering should (1) produce thermal deviation excess of the cell parameters and (2) lead to different variations of the $(h k l)$ peak intensities, and therefore could be detected by the variation of the intensity ratio as function of temperature.

\section{Thermal expansion coefficients along the calcite-dolomite join}

High-temperature single crystal (Markgraf and Reeder 1985; Reeder and Markgraf 1986) and powder (Antao et al. 2009; De Aza et al. 2002; Merlini et al. 2016) diffraction experiments have been conducted on calcite, dolomite and magnesite. The relative thermal expansion of the cell parameters $a / a_{293} k, c / c_{293} k$ of OCN calcite, OCN magnesite and synthetic MgCc50 dolomite are compared to those of these previous data in Supp. Mat. Fig. S4. The comparison shows (1) a good agreement between OCN crystal data with powder diffraction experiments, but small discrepancies with single crystal experiments, (2) a marked deviation at about $773 \mathrm{~K}\left(T_{\text {diff }}\right)$ for synthetic $\mathrm{MgCc50}$ dolomite compared to $\mathrm{OCN}$ dolomite. Similarly, the relative thermal expansion of the cell parameters for OCN calcite, synthetic MgCc10, MgCc24 MgCc40, and MgCc50 are presented in Supp. Mat. Fig. S5. The Fig. illustrates (1) the change of slope of the a parameter as a function of temperature, from negative to positive, at about $10 \mathrm{~mol} \% \mathrm{MgCO}_{3}$ (Supp. Mat. Fig. S5a), and (2) the deflection of slope of the $c$ parameter as a function of temperature, at about $653 \mathrm{~K}\left(T_{\text {diff }}\right)$ (Supp. Mat. Fig. S5b). The thermal coefficients obtained by fitting the data to the usual second order polynomial curve are reported in Table 4 . The coefficient of thermal expansion of parameter $x(x=a, \operatorname{cor} V) \alpha_{x}=(1 / x)(d x / d T)$ is obtained by differentiating the polynomial expression of the thermal expansion $x=f(T)$ and then dividing by the $x$ parameter (Dubrovinsky 2002).

The mean coefficient of thermal expansion over the temperature range from $T_{1}$ to $T_{2}$ is expressed as $\overline{\alpha_{X}}=\int_{\mathrm{T} 1}^{\mathrm{T} 2} \alpha_{\mathrm{x}} \times \mathrm{dT} / \int_{\mathrm{T} 1}^{\mathrm{T} 2} \mathrm{dT}$. Because of the noticeable deviation of the thermal unit cell parameters at $T_{\text {dif, }}$ the mean thermal expansion coefficients $\overline{\alpha_{a}}, \overline{\alpha_{c}}$ and $\overline{\alpha_{V}}$ are calculated below and above $T_{\text {dif, }}$. e. within two temperature ranges: $293 \mathrm{~K}-653 \mathrm{~K}$ (LT) and 653 $\mathrm{K}-1073 \mathrm{~K}(\mathrm{HT})$. The mean thermal expansion coefficients for the cell parameters are compared to those of OCN calcite, magnesite and dolomite (De Aza et al. 2002) in Fig. 12, no measurements on $\mathrm{OCN}$ dolomite was realized by ourselves.

The particular features of the thermal expansion coefficients of calcite, dolomite and magnesite, in both low- and high-T ranges, are 1) the negative $\overline{\alpha_{a}}$ of calcite and 2) all coefficients of dolomite lie off of the calcite-magnesite line. These particularities were comprehensively studied and discussed by (Markgraf and Reeder 1985; Reeder and Markgraf 1986). In the Ca-Mg carbonate structure, the variation of the $c$ parameter is related to the variation of lateral oxygen bonds of the $(\mathrm{Ca}, \mathrm{Mg}) \mathrm{O}_{6}$ octahedra, while the variation of the $a$ parameter is related to the variation of basal oxygen bond which is limited by the resistance 


\begin{tabular}{|c|c|c|c|c|c|c|c|}
\hline & & $\alpha \times 653 \mathrm{~K}\left(10^{-5} \mathrm{~K}^{-1}\right)$ & $\alpha_{\mathrm{X} 923 \mathrm{~K}}\left(10^{-5} \mathrm{~K}^{-1}\right)$ & $\mathrm{X}_{0}$ & $\mathrm{X}_{1}\left(10^{-5} \cdot \mathrm{K}^{-1}\right)$ & $\mathrm{X}_{2}\left(10^{-8} \cdot \mathrm{K}^{-2}\right)$ & References \\
\hline & $\begin{array}{c}\text { parameters X } \\
\left(\AA, \AA^{3}\right)\end{array}$ & $293 \mathrm{~K}<\mathrm{T}<653 \mathrm{~K}$ & $\begin{array}{c}653 \mathrm{~K}<\mathrm{T}<923 \\
\mathrm{~K}\end{array}$ & & & & \\
\hline \multirow[t]{3}{*}{ Calcite } & $a$ & -0.462430 & -0.35238646 & 4.991380 & -2.992400 & 1.651090 & $\begin{array}{c}\text { Floquet } \\
2015\end{array}$ \\
\hline & $c$ & 2.879871 & 3.09441674 & 17.053300 & 45.205000 & 10.152000 & \\
\hline & V & 1.946290 & 2.37520437 & 367.94400 & 533.66000 & 456.60000 & \\
\hline \multirow[t]{3}{*}{$\mathrm{MgCc} 10$} & $\bar{a}$ & -0.142341 & -0.00435799 & 4.952266 & -2.232100 & 1.670167 & $\begin{array}{c}\text { Floquet } \\
2015\end{array}$ \\
\hline & $c$ & 2.765296 & 2.94037101 & 16.734160 & 41.563489 & 6.076303 & \\
\hline & $V$ & 2.477873 & 2.93080465 & 355.435213 & 554.827012 & 372.619230 & \\
\hline \multirow[t]{3}{*}{$\mathrm{MgCc} 24$} & $\bar{a}$ & 0.163899 & 0.25715705 & 4.900691 & -0.096501 & 1.025117 & \\
\hline & $c$ & 2.766580 & 2.760282 & 16.498839 & 45.766889 & 0.114855 & \\
\hline & $\bar{V}$ & 3.097712 & 3.28500822 & 343.171514 & 933.115278 & 153.983152 & \\
\hline \multirow[t]{3}{*}{$\mathrm{MgCc} 40-1$} & $a$ & 0.434491 & 0.54096424 & 4.837140 & 1.158570 & 1.068103 & \\
\hline & $c$ & 2.701174 & 2.52356043 & 16.149320 & 49.132930 & -5.866155 & \\
\hline & $\bar{V}$ & 3.579215 & 3.62828059 & 327.244200 & 1148.113210 & 37.903090 & \\
\hline \multirow[t]{3}{*}{$\mathrm{MgCc} 40-2$} & $\bar{a}$ & 0.466206 & 0.57499191 & 4.831066 & 1.153930 & 1.189404 & \\
\hline & $c$ & 2.678535 & 2.48017763 & 16.237620 & 45.986310 & -6.918950 & \\
\hline & $V$ & 3.620646 & 3.644942 & 325.567100 & 1156.664000 & 33.493130 & \\
\hline \multirow[t]{3}{*}{$\mathrm{MgCc} 50$} & $\bar{a}$ & 0.513846 & 0.643788 & 4.801714 & 0.968444 & 1.587677 & \\
\hline & $c$ & 2.519860 & 2.266482 & 15.899370 & 53.065870 & -11.783200 & \\
\hline & V & 3.557747 & 3.580010 & 317.479300 & 1182.483000 & -11.375760 & \\
\hline \multirow[t]{3}{*}{ Dolomite } & $\bar{a}$ & 0.546529 & 0.704501 & 4.803719 & 1.159773 & 1.652530 & $\begin{array}{c}\text { De Aza } \\
2002\end{array}$ \\
\hline & $c$ & 2.410878 & 2.768941 & 15.924700 & 26.210036 & 13.255800 & \\
\hline & $\bar{V}$ & 3.514414 & 4.209588 & 318.261370 & 667.070207 & 502.375754 & \\
\hline \multirow[t]{3}{*}{ Magnesite } & $a$ & 0.708000 & 0.770483 & 4.62600 & 2.828820 & 0.48015 & \\
\hline & $c$ & 2.371147 & 2.457921 & 14.91929 & 33.3164 & 2.568100 & \\
\hline & $\bar{V}$ & 3.787114 & 3.975891 & 276.504425 & 952.21804 & 118.59584 & \\
\hline
\end{tabular}

Table 4 Thermal expansion coefficients of unit cell parameters obtained by fitting the data to the expression $\mathrm{X}(\mathrm{T})=\mathrm{X}_{0}+\mathrm{X}_{1} \times 10^{-5} \mathrm{~T}+\mathrm{X}_{2} \times 10^{-5} \mathrm{~T}^{2} ; \overline{\alpha_{\mathrm{X}}}=\left(\int_{\mathrm{T} 1}^{\mathrm{T} 2} \alpha_{\mathrm{X}} \times \mathrm{d} T / \int_{\mathrm{T} 1}^{\mathrm{T} 2} \mathrm{~d} T\right) 10^{-5} \mathrm{~K}^{-1}$ is the mean linear thermal coefficient between $T_{1}$ and $T_{2}$, where $\alpha_{X}=(1 / x)(d x / d T)$ is the thermal expansion coefficient 
of parameter $\mathrm{x}(\mathrm{x}=a, c$ or $\mathrm{V}$ ) and $T$ is the temperature $(\mathrm{K})$. No thermal measurements on OCN dolomite was realized by ourselves

of rigid $\left(\mathrm{CO}^{2-}\right)_{3}$ groups. Accordingly, the thermal $c$ expansion and $a$ contraction in calcite is related to the strong anisotropy of the thermal expansion of the $\mathrm{CaO}_{6}$ octahedra and the large magnitude of libration of the $\left(\mathrm{CO}^{2-}\right)_{3}$ group (Markgraf and Reeder, 1985; Reeder and Markgraf, 1986). In magnesite, characterized by the $a$ and $c$ thermal expansion, the thermal expansion anisotropy of the $\mathrm{MgO}_{6}$ octahedra is moderate and the dominant motion of $\left(\mathrm{CO}^{2-}\right)_{3}$ group is the translation. In dolomite, the corner sharing between $\mathrm{CaO}_{6}$ and $\mathrm{MgO}_{6}$ octahedra in adjacent layers induces a lack of anisotropy of the $\mathrm{CaO}_{6}$ octahedra and a low amplitude of both libration and translation motions of the $\left(\mathrm{CO}^{2-}\right)_{3}$ group. Thus, the shift of the cell thermal expansion of dolomite from the calcite - magnesite line is explained by the perfect structural stacking alternating $\mathrm{Ca}$ and $\mathrm{Mg}$ basal planes on both sides of each $\mathrm{CO}_{3}$ plane. The systematic corner sharing between $\mathrm{CaO}_{6}$ and $\mathrm{MgO}_{6}$ octahedra in dolomite is ruled out in the disordered structures of $\mathrm{MgCc}$ calcites and dolomite. The thermal - structural relationships, as described by (Markgraf and Reeder 1985; Reeder and Markgraf 1986), imply that the thermal behavior of the synthetic $\mathrm{MgCc}$ calcites and $\mathrm{MgCc50}$ dolomite is dependent of the structural arrangement of the $\mathrm{CaO}_{6}$ and $\mathrm{MgO}_{6}$ octahedra. The thermal coefficients are expected in the calcite - dolomite line for fully disordered MgCc calcites. Thus, a thermal coefficient excess from the calcite - dolomite line would be characteristic of the structural order of $\mathrm{CaO}_{6}$ and $\mathrm{MgO}_{6}$ octahedra.

In the low- and high-T range (Fig. 12), the mean thermal expansion coefficients of the synthetic $\mathrm{MgCc}$ calcites and $\mathrm{MgCc50}$ dolomite lie off of both calcite-dolomite and calcite-magnesite lines. In the low- $T$ range (Figs. 12 a to $c$ ), a significant positive deviation from the calcitedolomite line is observed for the $\overline{\alpha_{a}}$ and $\overline{\alpha_{V}}$ coefficients, with a maximum deviation close to 25 mol\% $\mathrm{MgCO}_{3}$ for $\overline{\alpha_{a}}$. Conversely, the $\overline{\alpha_{c}}$ coefficients lie in between calcite - dolomite and calcite - magnesite line. In the high-T range, positive deviation from calcite-dolomite line occurs for the $\overline{\alpha_{a}}$ coefficients (Fig. 12d). On the contrary, large negative deviation are observed for the $\overline{\alpha_{c}}$ and $\overline{\alpha_{V}}$ coefficients (Figs. 12 e and f).

For the synthetic MgCc calcites and MgCc50 dolomite, in the LT range $273 \mathrm{~K}-653 \mathrm{~K}$, the thermal expansion excess (with respect to the calcite-dolomite line) is positive for $a, c$ and $V$ $\left(\Delta \overline{\alpha_{a}}=1 \times 10^{-6}, \Delta \overline{\alpha_{c}}=1 \times 10^{-6}, \Delta \overline{\alpha_{V}}=3 \times 10^{-6}\right)$. These results are consistent with the thermalstructural relationships proposed by (Markgraf and Reeder 1985; Reeder and Markgraf 1986), and could be related to the state of order-disorder as do the cell parameters that are similarly deviating from the calcite-dolomite line (Fig. 4). In the HT range, excess is unchanged for $a$ $\left(\Delta \overline{\alpha_{a}}=1 \times 10^{-6}\right)$ but largely negative for $c$ and $V\left(\Delta \overline{\alpha_{c}}=-5 \times 10^{-6}, \Delta \overline{\alpha_{V}}=-3 \times 10^{-6}\right)$. The differences observed between the low- and high-T range comes from the positive and negative inflection of the $a$ and $c$ parameters respectively, starting at $T_{\text {diff }}$ in all synthetic MgCc (Figs. 11 and Supp. Mat. Fig. S3) whereas not recorded in OCN dolomite powder (De Aza et al. 2002; Merlini et al. 2016) and in dolomite single crystal (Reeder and Markgraf 1986) (Supp. Mat. Fig. S4). 

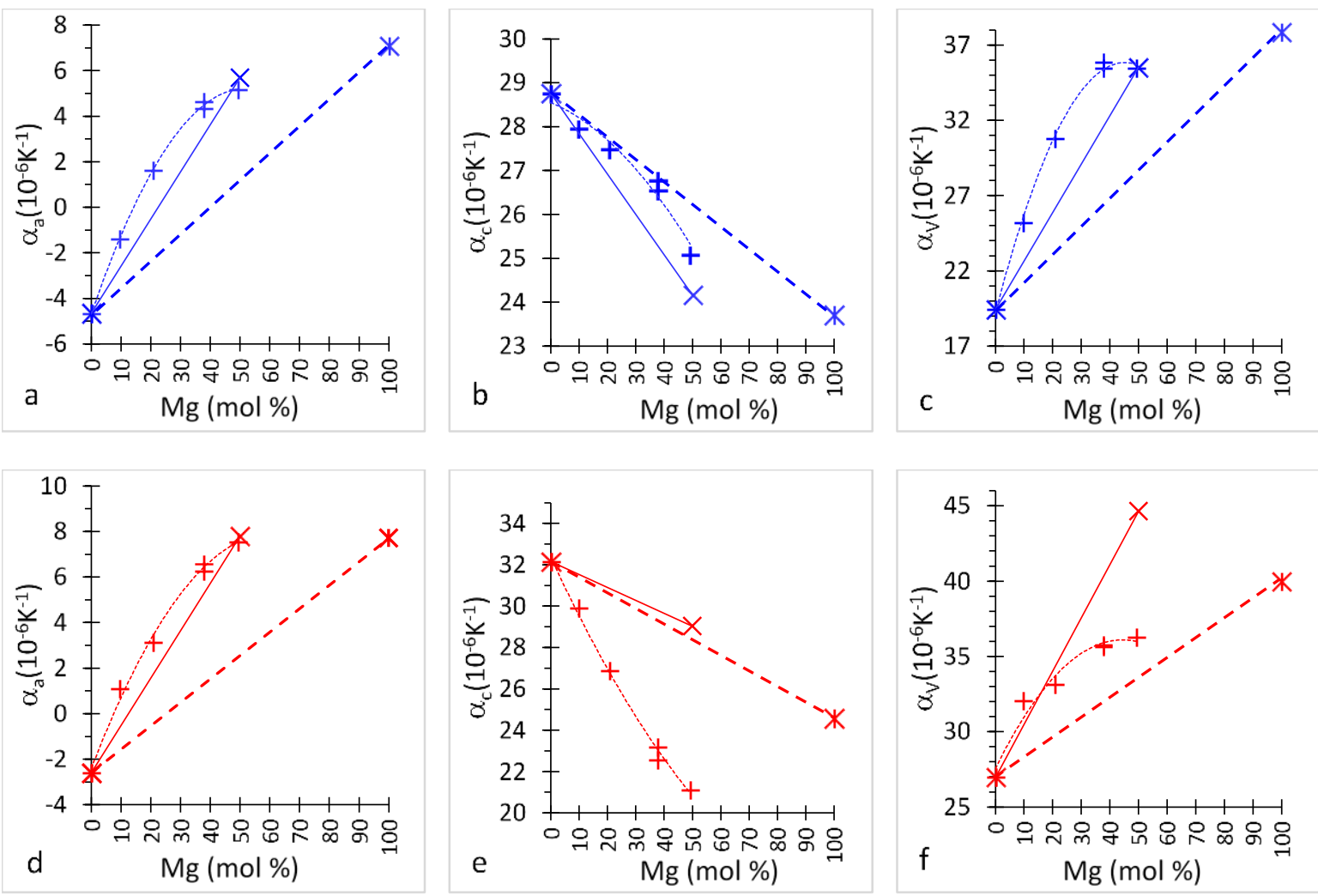

554

555

556

557

558

559

560

561

562

563

564

565

566

567

568

569

570

571

572

573

574

Fig. 12 Mean thermal expansion coefficients of the cell parameters $\alpha_{a}, \alpha_{c}$ and $\alpha_{v}$ as a function of $M g$ content for OCN calcite and OCN magnesite (double crosses), natural dolomite (De Aza 2002) (crosses), and for synthetic MgCc10, MgCc24, MgCc40 and MgCc50 (plus) : a to c Low-temperature ranges (293-673 K) (blue) and d to f high-temperature ranges (653-923 K) (red)

\section{Intensities and FWHMs of the Bragg peaks as a function of T. Interpretation of the data.}

In the case of MgCc24 both intensity effects are detected. The variations of the $\left(\begin{array}{lll}1 & 0 & 4\end{array}\right)$ peak intensities as a function of $T$ for MgCc24 are shown in Fig. 13a. The regular shift of the $\left(\begin{array}{lll}1 & 0 & 4\end{array}\right)$ peak towards lower $2 \theta$ values is due to the progressive change of cell parameters with temperature. Concerning intensities, different zones can be defined: (1) intensities increase between $293 \mathrm{~K}$ and $413 \mathrm{~K},(2)$ intensities decrease regularly between $413 \mathrm{~K}$ and $713 \mathrm{~K}$ (= $T_{\text {dif }}$ ), (3) a plateau is observed between $T_{\text {dif }}(713 \mathrm{~K})$ and $T_{P D}(953 \mathrm{~K})$, (4) intensities decrease past $\mathrm{T}_{\mathrm{PD}}$. Interestingly, the two patterns determined at RT before (initial sample) and after annealing (remaining undecomposed sample) are almost identical (Supp. Mat. Table S1). Besides, the

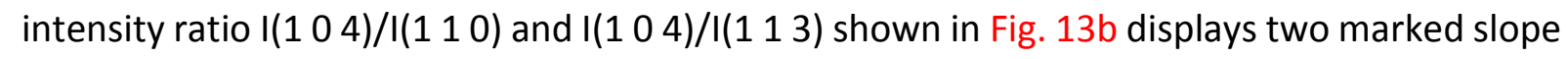
disruptions at $713 \mathrm{~K}$ and $953 \mathrm{~K}$ relevant to both diffusion and decomposition processes. However, no notable FWHM effect on the Bragg peaks was detected. The variations of $(h k l)$ FWHMs as a function of $T$ are unrelated to the $\mathrm{Mg}$ content of the samples, the variations among different samples are not significant (Supp. Mat. Table S1), and no irregularity is observed even for ( $h k l)$ peaks with large / values such as (l $\left.\begin{array}{lll}0 & 1\end{array}\right)\left(\begin{array}{lll}0 & 0 & 12\end{array}\right)\left(\begin{array}{lll}0 & 2 & 10\end{array}\right)$ and (l 1112$)$. 
575 Concerning the synthetic dolomite $\mathrm{MgCc50}, T_{\text {dif }}$ equals $T_{\mathrm{PD}}$ and normal and $b$-type peak 576 intensities display different behaviors. Normal peak intensities (e.g. 00 6) plotted in Fig. 14 577 decrease progressively up to $T_{\text {dif }}=T_{P D}=773 \mathrm{~K}$, then faster above $T_{\text {dif. }}$. This observation is valid 578 for all normal peaks. On the other hand, $b$-type peak intensities [e.g. (l 15$)$ ] decrease up to $579 T_{\text {dif, }}$ then increase up to $1013 \mathrm{~K}$ (Fig. 14).
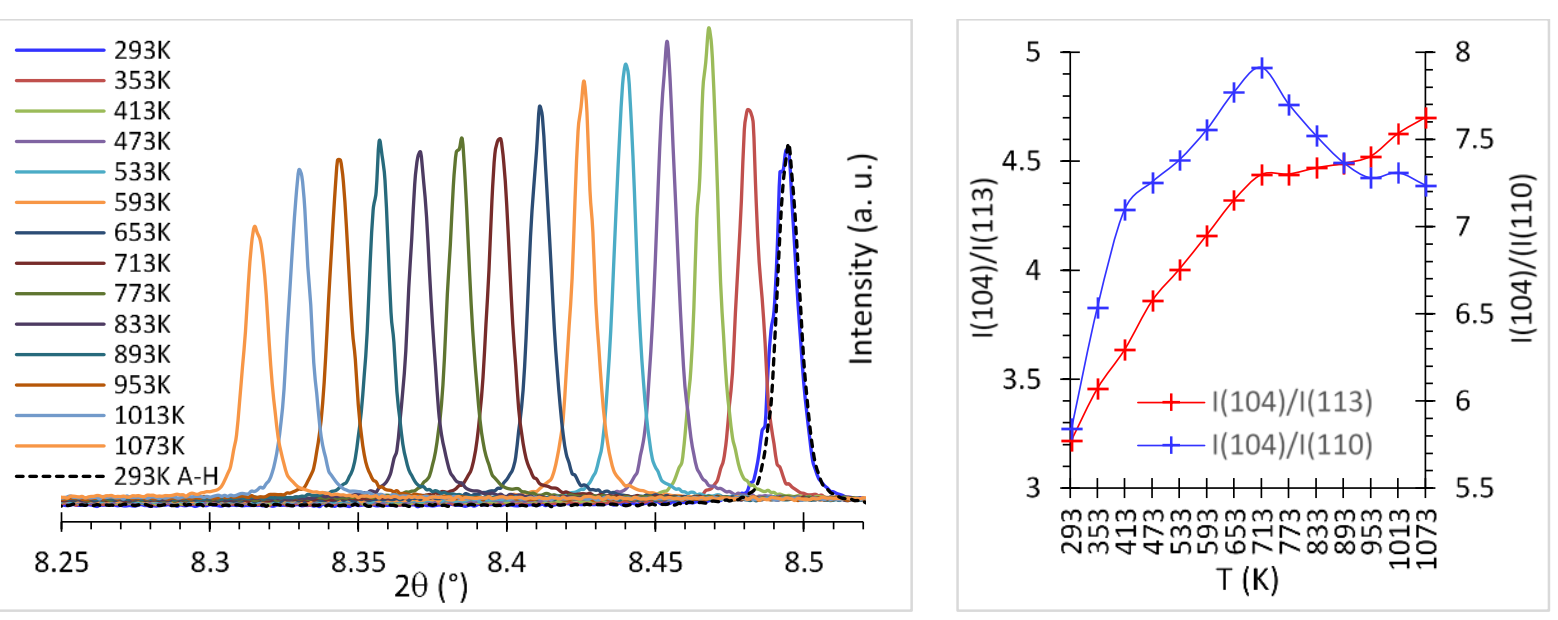

580

581

582

Fig. 13 a) Bragg (1 0 4) diffraction peaks for MgCc24; b) Intensity ratio I(1 0 4)/I(1 13 3) and I(1 0 4)/I( 583 10 ) for MgCc24 (wavelength of $\lambda=0.41068(1) \AA(30 \mathrm{keV})$ ) recorded from $\mathrm{RT}$ to $\mathrm{T}=1073 \mathrm{~K}$. Note the slope breaks at $713 \mathrm{~K}$ and $953 \mathrm{~K}$
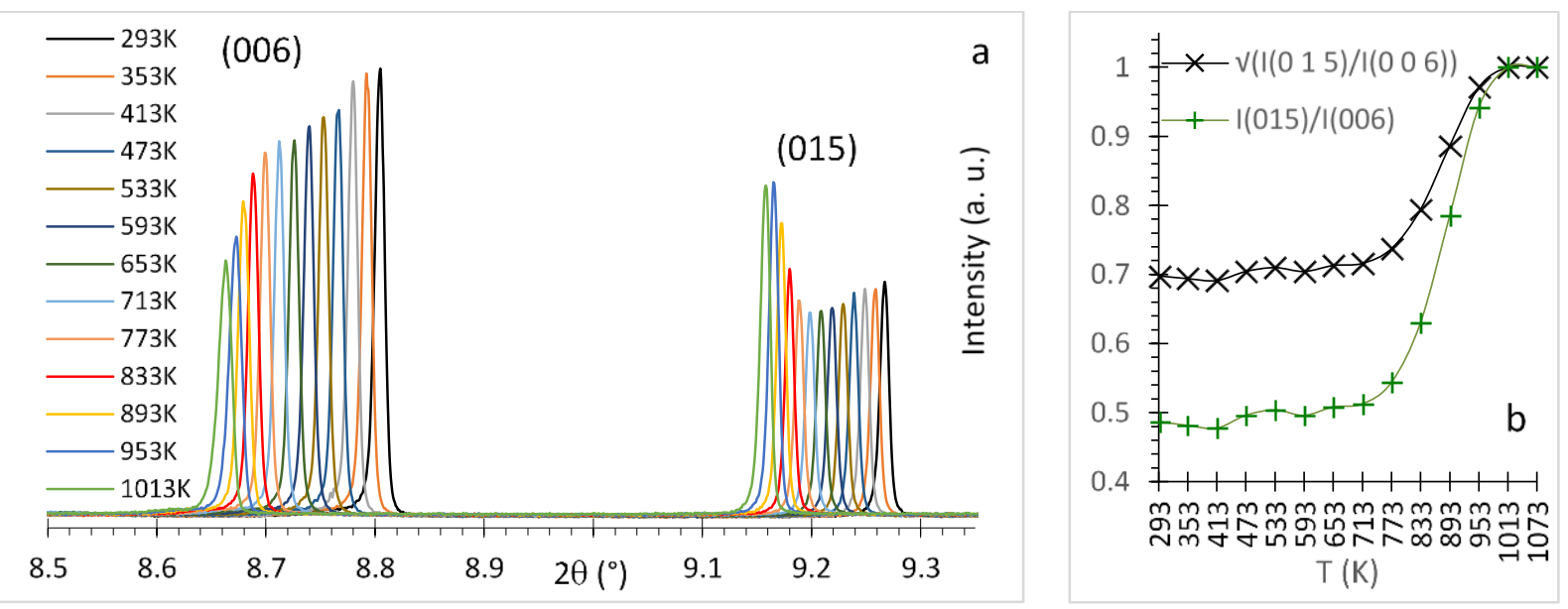

584

585

Fig. 14 a) HRXRPD patterns in the $2 \theta$ range corresponding to the (0 06$)$ and $(015)$ peaks; b) Intensity

586

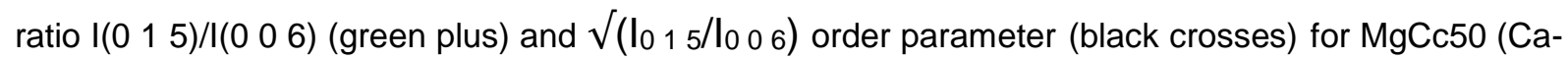
587 dolomite) from RT to $T=1073 \mathrm{~K}$ (wavelength of $\lambda=0.41068(1) \AA(30 \mathrm{keV})$ )

588 These data indicate that cation long-range reordering within the dolomite structure starts at $589773 \mathrm{~K}$. The order parameter $\sqrt{\left(\mathrm{l}_{1}{ }_{5} / \mathrm{l}_{0} 0_{6}\right)}$ shows that the MgCc50 dolomite is almost fully 590 ordered at $T=1073 \mathrm{~K}$, with less than $10 \%$ cation disordering (Fig. 14b) which is not surprising 591 since ordered dolomite is expected at $1073 \mathrm{~K}$. (Hammouda et al. 2011; Zucchini et al. 2012). 592 In addition, (Goldsmith et al. 1961; Reeder and Wenk 1983) concluded that cation ordering in 
dolomite results in a decrease of $c$ and a slight increase of $a$, thus a marked decrease of the $c / a$ ratio. Data reported above with $c / a$ of $\mathrm{MgCc50}$ deviating from linearity at $T_{\text {dif }}$ (Supp. Mat. Fig. S3) is interpreted as an effect of cation ordering activated by temperature, in a disordered dolomite initially synthesized at $1373 \mathrm{~K}$. Similarly to $\mathrm{MgCc50}$, the changes of cell parameters arising at $T_{\text {dif }}=653 \mathrm{~K}, 673 \mathrm{~K}$ for $\mathrm{MgCc} 10, \mathrm{MgCc} 24$ and $\mathrm{MgCc} 40$ are interpreted in terms of ordering process in partially disordered $\mathrm{Mg}$ calcite samples synthesized at $1273 \mathrm{~K}$ or $1373 \mathrm{~K}$. Note that in the case of $\mathrm{MgCc} 50$, both short- and long-range ordering is implicated while in more calcitic syntheses only short-range ordering would be implied. Summarizing, in the range $\mathrm{RT}-T_{\text {dif, }}$ the variation of cell parameters is simply due to a thermal effect. Above $T_{\text {dif, }}$ both thermal effect and cation ordering affect the cell parameters. More interactive and interlinked effects are expected once the partial decomposition starts.

\section{Discussion}

\section{Comparison with previous data and interpretation of high-Mg calcite XRD patterns}

Our data are consistent with previous experimental studies (Byrnes and Wyllie 1981; Goldsmith et al. 1955; Goldsmith and Heard 1961; Harker and Tuttle 1955; Irving and Wyllie 1975; Newton et al. 1969) that predict a continuous (or almost continuous) solid solution between $\mathrm{CaCO}_{3}$ and $\left(\mathrm{Ca}_{0.5} \mathrm{Mg}_{0.5}\right) \mathrm{CO}_{3}$, in the pressure and temperature conditions of our experiments. Indeed, (Goldsmith and Heard 1961) locate the top of the calcite-dolomite solvus at a temperature of $1348 \mathrm{~K}$ and a composition of $43 \mathrm{~mol}^{2} \mathrm{MgCO}_{3}$. The variation of cell parameters as a function of composition are in agreement with most previous studies (Bischoff et al. 1983; Goldsmith et al. 1958; Goldsmith et al. 1961) but disagree with the results of (Zhang et al. 2010) that strongly deviate from previous data, particularly above $30 \mathrm{~mol} \%$ $\mathrm{MgCO}_{3}$ (Fig. 1).

The identification of two groups characterized either by narrow and symmetric peaks (low-Mg synthetic calcites: MgCc2-MgCc26) or broadened and asymmetric peaks (high-Mg synthetic calcites: $\mathrm{MgCc} 28$ to $\mathrm{MgCc} 45)$ is of major importance and deserves further interpretation. First of all, the features on which the separation into two groups are robust since (1) all MgCc above 26 mol\% $\mathrm{MgCO}_{3}$ display similar patterns, (2) higher temperatures ( $1373 \mathrm{~K}$ instead of $1273 \mathrm{~K}$ ) and pressure (1.5 GPa instead of $1 \mathrm{GPa}$ ) are not responsible for the peak widening because two of the high-Mg calcites (MgCc28 and 30) synthesized at $1273 \mathrm{~K}, 1 \mathrm{GPa}$ display similar broad peaks. Actually, the broadening of the peaks corresponds to (1) a compositional variability in the high-Mg calcites of the order of $\pm 1 \mathrm{~mol}^{2} \mathrm{MgCO}_{3}$, (2) a mean apparent strain $\langle\varepsilon\rangle$ of about $4 \times 10^{-3}$ against $2 \times 10^{-4}$ in low $\mathrm{Mg}$-calcites, (3) both effects of compositional heterogeneity. One of them could be related to compositional variation between crystals as determined by EMP of the order of $\pm 0.8 \mathrm{~mol} \% \mathrm{MgCO}_{3}$. But the second, finer level of compositional heterogeneity could be due to the coexistence in a given crystal of coherent scattering domains, the components of which have different cation ordering and slightly different compositions and are producing microstructural strain. The actual distribution of $\mathrm{Ca}$ and $\mathrm{Mg}$ in each microcrystal 
633

634

635

636

637

638

639

640

641

642

643

644

645

646

647

648

649

650

651

652

653

654

655

656

657

658

659

660

cannot be determined because the broadening of the diffraction peaks depends also on the strain, size and distribution of the coherent scattering domains. Nanoscale heterogeneous microstructures are very common in Ca rich dolomite natural samples. They were reported in numerous HRTEM studies by interpreting HAADF image modulations and satellite reflections in the diffraction patterns (Fang and Xu 2019; Larsson and Christy 2008; Meike et al. 1988; Reksten 1990; Shen et al. 2014; Van Tendeloo et al. 1985; Wenk et al. 1991). But actually, if many microstructures were proposed at the nanometric scale, no further structural details of the domain model would be provided at the micrometric scale by single crystal diffraction method (Reeder 2000) - natural dolomites with 44 and $45.5 \mathrm{~mol}^{2} \mathrm{MgCO}_{3}-$ Sorder $=0.84$ and 0.71 ) and by comprehensive Rietveld techniques (Drits et al. 2005) natural dolomites with $45.1,47.8$ and $48.4 \mathrm{~mol}_{\mathrm{O}} \mathrm{MgCO}_{3}$ ). Considering all this, it is very likely that the constraints on cation order in Ca rich dolomite similarly occur in the high-Mg synthetic calcite. Clearly, further studies are required to validate the nanoscale compositional heterogeneity, but additional valuable insights at the short-range-order scale could be given from our previous Raman data (Perrin et al. 2016), as discussed below.

\section{Length scales of the cationic disorder state}

Unit-cell parameters and volume obtained for all the MgCc samples show small deviations from the almost straight calcite-dolomite-magnesite line. Assuming that a total disordered $\mathrm{MgCc}$ corresponds to an ideal solid solution and plots along the straight line, the strain associated with the partial order ( $p$-ord) - total disorder ( $t$-dis) transformation is defined as $\varepsilon x$ $=\left(X_{p \text {-ord }}-X_{t-\text { dis }}\right) / X_{t \text {-dis }}=\Delta X / X_{t \text {-dis }}$ where $X_{p \text {-ord }}$ is the value of $a, c$ or $V$ obtained for a MgCc sample and $X_{t-d i s}$ is the value of $a, c$ or $V$ calculated for the same composition from the straight line through the end-members. The strains $\varepsilon_{\mathrm{a}}, \varepsilon_{\mathrm{c}}, \varepsilon_{\mathrm{V}}$ calculated for the $a, c$ and $V$ parameters, for all the MgCc samples are plotted as a function of the Mg content in Fig. 15.
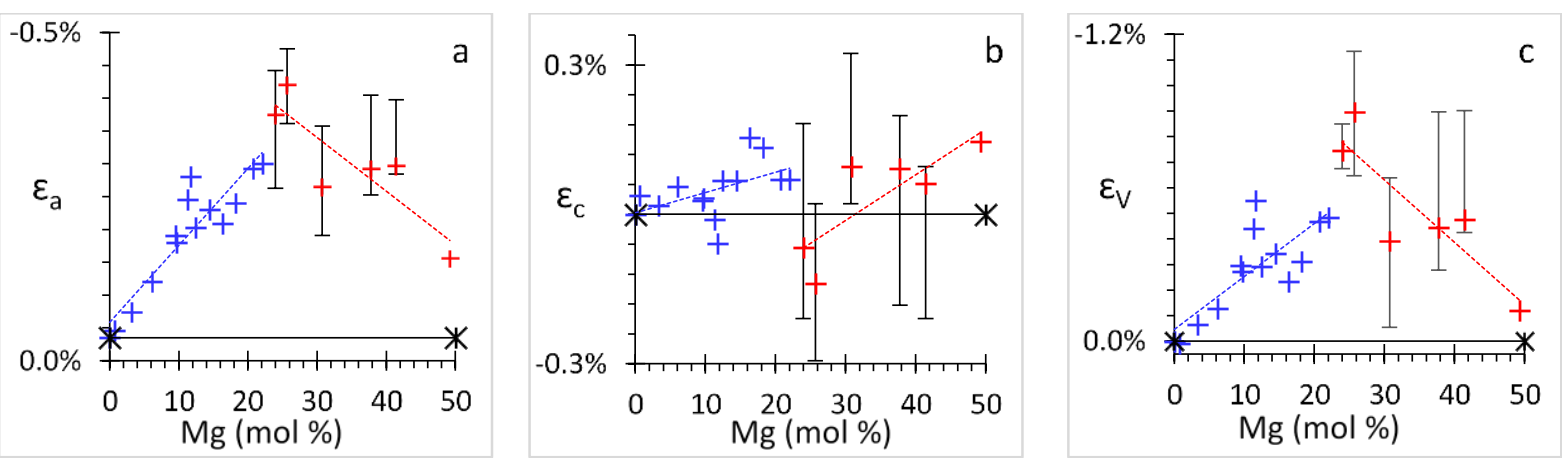

Fig. 15 Strain in magnesian calcites at RT as a function of Mg content a) $\varepsilon_{a}$; b) $\varepsilon_{c}$; c) $\varepsilon v$; (black: OCN calcite and OCN dolomite; blue: low-Mg synthetic samples; red: high-Mg and MgCc50 synthetic samples) 
The strain values are negative for $\varepsilon_{a}$ and $\varepsilon v$ and generally positive for $\varepsilon_{c}$; they display different behavior for low- and high-Mg synthetic calcites. In the range 0-22 mol\% $\mathrm{MgCO}_{3}$ (low-Mg: $\mathrm{MgCc}$ to 26), all strain values increase as the $\mathrm{Mg}$ content increases, while in the high-Mg synthetic calcites, $\varepsilon_{a}$ and $\varepsilon v$ decrease, and $\varepsilon_{c}$ increases. The transition between the two groups is marked by a discontinuity (negative jumps for $\varepsilon_{a}$ and $\varepsilon_{v}$, negative for $\varepsilon_{c}$ ). In the carbonate structure, strongly bonded coplanar $\left(\mathrm{CO}_{3}\right)^{2-}$ groups are arranged parallel to the $\left(\begin{array}{lll}0 & 0 & 1\end{array}\right)$ plane and connected through much weaker bonds to 6 -coordinated divalent cations. Thus, the negative strain along the $a$ axis could be related to the distance $\mathrm{O}_{1}-\mathrm{O}_{2}$ of the $\mathrm{MO}_{6}$ octahedra $(\mathrm{M}=\mathrm{Ca}$ or $\mathrm{Mg})$, connecting two rigid $\left(\mathrm{CO}_{3}\right)^{2-}$ carbonate groups in the $\left(\begin{array}{lll}0 & 0 & 1\end{array}\right)$ plane. On the other hand, the positive strain along the $c$-axis could be related to the variation of $\mathrm{O}_{1}-\mathrm{O}_{6}$ bond in the $\mathrm{MO}_{6}$ octahedra. Cation ordering affects the orientation of the $\left(\mathrm{CO}_{3}\right)^{2-}$ groups (1) by their rotation $(\delta)$ around the $c$ axis and (2) tilting out $(\gamma)$ of the carbonate groups in the $\left(\begin{array}{ll}0 & 0\end{array}\right)$ plane. The rotation generates a negative $a$ strain, while tilting generates a positive $c$ strain. On this basis, both in-plane rotation $(\delta)$ and tilting out $(\gamma)$ of the $\left(\mathrm{CO}_{3}\right)^{2-}$ groups increase as the $\mathrm{Mg}$ content increases in the low-Mg calcites, whereas in-plane rotation $(\delta)$ decreases and tilting out $(\gamma)$ increases in the high-Mg calcites, as the $\mathrm{Mg}$ content increases. The basal rotation $(\delta)$ and tilting out $(\gamma)$ of the $\left(\mathrm{CO}_{3}\right)^{2-}$ groups are maximal at 25 and $50 \mathrm{Mg}$ mol. \%, respectively. The above correlation indicates that the deviation with respect to an ideal solid solution in the calcite-dolomite range is related to the local ordering or clustering of $\mathrm{Ca}$ and $\mathrm{Mg}$ in cation layers involving reorientation of $\left(\mathrm{CO}_{3}\right)^{2-}$ groups, associated with an inverse strain of the unit cell parameters, negative for $a$ and positive for $c$.

Neither loss of rotational symmetry, nor long range cation ordering is observed by X-ray diffraction in the synthetic magnesian calcites, only structural distortion. Thus partial ordering can only be short-range. This conclusion is in agreement with the Raman study of the same synthetic magnesian calcites reported in a previous study (Perrin et al. 2016). As shown in Supp. Mat. Fig. S6, the FWHMs of the Raman bands change as a function of Mg content and type of vibrations within the $\left(\mathrm{CO}_{3}\right)^{2-}$ groups [bending deformation modes (doubly degenerate $\mathrm{Eg}$ ) that involve both carbon and oxygen motion, and stretching mode (A1g) which is like the respiration mode of oxygen]. A comparison of Figs. 15 and S6 shows that the unit cell strain determined by XRD and the Raman band enlargement are correlated. The strain $\varepsilon_{a}$ for the $a$ parameter (Fig. 15a) and the FWHM of the bending modes [particularly the internal translation mode (T) (Supp. Mat. Fig. S6a) are similar]. On the other hand, the strain $\varepsilon_{c}$ for the $c$ parameter (Fig. 15b) is more consistent with the enlargement observed for the single stretching mode $v 1$ (Supp. Mat. Fig. S6e). Below 25\% Mg content, the heterogeneity between local cationic configurations increases inside the crystals. Above $25 \% \mathrm{Mg}$ content, the single phase - multi-phase transition from homogeneous to heterogeneous crystals linked to the strain relaxation is marked for both modes with a decrease of the local cationic configuration heterogeneity towards dolomite like ordering. The heterogeneous MgCc crystals could be 
made of different domains with different local ordering configurations having similar or slightly different magnesium contents.

Thus, both the bending deformation and stretching modes observed by Raman spectroscopy can be related to the two types of site-symmetry of the $\left(\mathrm{CO}_{3}\right)^{2-}$ group: the off planar tilting $(\gamma)$ and the in plane rotation $(\delta)$, respectively. The genetic connection between the off plane tilting $(\gamma)$ specific to the dolomite structure and the stretching mode $\left(v_{1}, \mathrm{~A} 1 \mathrm{~g}\right)$ is also supported by the out of plane bending mode Raman peak $\left(v_{2}, \mathrm{~A} 2 \mathrm{~g}\right)$. This peak, which is active in dolomite structure, is weak in synthetic magnesian calcites but can be detected from about $10 \mathrm{~mol}$ \% $\mathrm{MgCO}_{3}$ and its intensity progressively increases thereafter until 50 mol\% $\mathrm{MgCO}_{3}$ (Perrin et al. 2016). As seen above, the synthetic MgCc50 dolomite is characterized by $36 \%$ cation disordering in both types of cationic layers. No anomalous intensity (except for the $b$-type reflection) nor FWHM broadening of the $(h k l)$ peaks (potentially indicative of ordered stacking sequence) were detected. The cation disordering corresponds to the maximal positive strain of the $c$ parameter. A medium negative strain of the $a$ parameter is observed (Fig. 15). Short-range disordering can be characterized from previous Raman data. As observed in Supp. Mat. Fig. S6, both enlargement of the stretching mode ( $\left.v_{1}, \mathrm{~A} 1 \mathrm{~g}\right)$ and intensity of the dolomite bending mode ( $\left.2 v_{2}, \mathrm{~A} 2 \mathrm{~g}\right)$ are maximal (Fig. 7 in (Perrin et al. 2016)), whereas enlargements of the other bending modes start decreasing above $25 \mathrm{~mol} \% \mathrm{MgCO}_{3}$. Thus, the short range $\mathrm{Ca}, \mathrm{Mg}$ disorder set to $36 \%$ from $\sqrt{\left(\mathrm{l}_{0} \mathrm{1}_{5} / \mathrm{I}_{0} 0_{6}\right)}$ order parameter, is characterized by a decrease of the $a$ parameter, an increase of the $c$ parameter, and an increase of both in plane rotation and off-plane tilting variability.

\section{Conclusion}

These data confirm the presence of an almost continuous solid-solution between calcite and dolomite above $1273 \mathrm{~K}$, and the presence of a second-order transition between long-range disordered $\mathrm{Mg}$ calcite and dolomite in the interval $41-49 \mathrm{~mol} \% \mathrm{MgCO}_{3}$ at $1373 \mathrm{~K}$. In the $\mathrm{Mg}$ calcites, the deviation from the Cc-Dol straight line in the $a / \mathrm{Mg}, c / \mathrm{Mg}$, or $V / \mathrm{Mg}$ diagrams is interpreted in terms of cationic short-range ordering in the $\mathrm{Mg}$ calcites. This short-range order is accompanied by in plane rotation and the off planar tilting of the $\left(\mathrm{CO}_{3}\right)^{2-}$ groups in the anion layer that are maximal at 25 and $50 \mathrm{Mg}$ mol. \%, respectively. As a result, the role of $\left(\mathrm{CO}_{3}\right)^{2-}$ group ordering is an important factor in the crystal structure of Ca-Mg carbonate. The thermal expansion of MgCc10, 24, 40 and 50 have been determined up to 650-750K. The thermal expansivity deviates from the Cc-Dol straight line. Compared with calcite, dolomite and magnesite previous results, this trend is interpreted in terms of interactive contributions of $\mathrm{CaO}_{6}$ and $\mathrm{MgO}_{6}$ octahedra and $\mathrm{CO}_{3}$ groups to the thermal expansion and thus explained by the structural short-range ordering observed at RT. At higher temperatures complications arise from cation reordering or partial decomposition of the samples. The excess of thermal expansion coefficients from the Cc-Dol straight line are consistent with the thermal-structural relationships proposed by (Markgraf and Reeder 1985; Reeder and Markgraf 1986), and 
supports the cationic short range ordering in the $\mathrm{Mg}$ calcites. The peak width of the diffractograms allow separating the synthetic Mg calcites into two groups: low- and high-Mg synthetic calcites. Low-Mg synthetic calcites are homogeneous in $\mathrm{Mg}$ content while high-Mg synthetic calcites display domains with slight differences in $\mathrm{Mg}$ content and degree of shortrange order. The short-range $\mathrm{Ca}, \mathrm{Mg}$ disorder could be at random or set into a mosaic of the different planar ordering configurations reported in TEM studies for dolomite and Ca rich dolomite(Fang and Xu 2019; Larsson and Christy 2008; Meike et al. 1988; Reksten 1990; Shen et al. 2014; Van Tendeloo et al. 1985; Wenk et al. 1983) and by computer simulation approach (Burton and Van de Walle 2003; Lacivita et al. 2017; Reeder 2000; Wang et al. 2011). Further studies are required to better characterize the size and spatial distribution of these domains. One of the ways to quantify the local ordering state at the length scale of a few unit cells could be to combine Z-contrast imaging from scanning transmission electron microscopy of appropriate samples and image simulation, a novel approach developed by (Fang and Xu 2019). This new complete series of structural data on $\mathrm{Mg}$ calcite including thermal properties, will serve as references in many fields of research involving synthetic crystals obtained in solution-based crystallization processes (nanocrystals, mesocrystals, calcite/polymers crystals), biogenic crystals and geological minerals. It will also provide a robust basis for studies to come on the physical chemistry of precipitation, dissolution and ionic diffusion of $\mathrm{Mg}$ carbonates, and for the thermodynamic modeling of solid solutions which is an important research topic in many areas of materials science and geoscience.

\section{ACKNOWLEDGMENTS}

This work has been supported by the Centre National de la Recherche Scientifique (CNRS) Institut National des Sciences de I'Univers (INSU) through grant INTERRVIE 2017 to DV, by the Agence Nationale pour la Recherche through ANR MOBi 2018, and by the Centre Interdisciplinaire de Nanoscience de Marseille (CINaM) through internal grants. We would like to thank A. Saùl and A. Ricolleau for constructive discussions. This is contribution ANR MOBi 2. We are grateful to the European Synchrotron Radiation Facility for providing access to the instruments and we would like to thank Andy Fitch for assistance in using beamline ID22.

\section{References}

Althoff PL (1977) Structural refinements of dolomite and a magnesian calcite and implications for dolomite formation in marine environment Am Mineral 62 (7-8):772-783

Antao SM, Hassan I, Mulder WH, Lee PL, Toby BH (2009) In situ study of the R-3c toR-3m orientational disorder in calcite. Phys Chem Miner 36 (3):159-169. doi:10.1007/s00269-0080266-y

Bischoff WD, Bishop FC, Mackenzie FT (1983) Biogenically produced magnesian calcite; inhomogeneities in chemical and physical properties; comparison with synthetic phases. Am Mineral 68 (11-12):1183-1188 
Burton BP, Van de Walle A (2003) First-principles-based calculations of the $\mathrm{CaCO}-\mathrm{MgCO} 3$ and CdCO3-MgCO3 subsolidus phase diagrams. Phys Chem Miner 30 (2):88-97. doi:10.1007/s00269-002-0294-y

Byrnes AP, Wyllie PJ (1981) Subsolidus and melting relations for the join $\mathrm{CaCO}-\mathrm{MgCO} 3$ at $10 \mathrm{kbar}$. Geochim Cosmochim Acta 45 (3):321-328. doi:https://doi.org/10.1016/0016-7037(81)902428

Cowley JM (1950) An Approximate Theory of Order in Alloys. Phys Rev 77 (5):669-675. doi:10.1103/PhysRev.77.669

Cowley JM (1960) Short- and Long-Range Order Parameters in Disordered Solid Solutions. Phys Rev 120 (5):1648-1657. doi:10.1103/PhysRev.120.1648

De Aza AH, Rodriguez MA, Rodriguez JL, De Aza S, Pena P, Convert P, Hansen T, Turrillas X (2002) Decomposition of dolomite monitored by neutron thermodiffractometry. J Am Ceram Soc 85 (4):881-888

Deelman JC (1999) Low-temperature nucleation of magnesite and dolomite. Neues Jahrbuch Fur Mineralogie-Monatshefte (7):289-302

Deelman JC (2011) Low-temperature formation of Dolomite and Magnesite. Compact Disc Publications Geology Series.Compact Disc Publications, Eindhoven, The Netherlands. http://www.jcdeelman.demon.nl/dolomite/bookprospectus.html

Drits VA, McCarty DK, Sakharov B, Milliken KL (2005) New insight into structural and compositional variability in some ancient excess-Ca dolomite. Can Mineral 43:1255-1290. doi:10.2113/gscanmin.43.4.1255

Dubrovinsky L (2002) Thermal Expansion and Equation of State. In: Buschow KHJ, Cahn RW, Flemings MC et al. (eds) Encyclopedia of Materials: Science and Technology. Elsevier, Oxford, pp 1-4. doi:https://doi.org/10.1016/B0-08-043152-6/01817-9

Fang YH, Xu HF (2019) A new approach to quantify the ordering state of protodolomite using xrd, tem, and z-contrast imaging. Journal of Sedimentary Research 89 (6):537-551. doi:10.2110/jsr.2019.29

Fitch AN (2004) The high resolution powder diffraction beam line at ESRF. Journal of Research of the National Institute of Standards and Technology 109 (1):133-142. doi:Doi 10.6028/Jres.109.010

Floquet N, Vielzeuf D, Ferry D, Ricolleau A, Heresanu V, Perrin J, Laporte D, Fitch AN (2015) Thermally Induced Modifications and Phase Transformations of Red Coral Mg-Calcite Skeletons from Infrared Spectroscopy and High Resolution Synchrotron Powder Diffraction Analyses. Crystal Growth \& Design 15 (8):3690-3706. doi:10.1021/acs.cgd.5b00291

Glover ED, Sippel RF (1967) Synthesis of magnesium calcites. Geochim Cosmochim Acta 31 (4):10. doi:10.1016/0016-7037(67)90037-3

Goldsmith JR, Graf DL, Chodos AA, Joensuu OI, Mcvicker LD (1958) Relation between lattice constants and composition of Ca-Mg carbonates. Am Mineral 43 (1-2):84-101

Goldsmith JR, Graf DL, Heard HC (1961) Lattice constants of the calcium magnesium carbonates. Am Mineral 46 (3-4_Part_1):453-459

Goldsmith JR, Graf DL, Joensuu OI (1955) The occurrence of magnesian calcites in nature. Geochim Cosmochim Acta 7 (5):212-230. doi:https://doi.org/10.1016/0016-7037(55)90033-8

Goldsmith JR, Heard HC (1961) Subsolidus Phase Relations in the System CaCO3-MgCO3. The Journal of Geology 69 (1):45-74. doi:10.1086/626715

Hammouda T, Andrault D, Koga K, T.Katsura, Martin A (2011) Ordering in double carbonates and implications for processes at subduction zones. Contrib Mineral Petrol 161:439-450. doi:10.1007/s00410-010-0541-z

Harker RI, Tuttle OF (1955) Studies in the system CaO-MgO-CO 2 ; Part 2, Limits of solid solution along the binary join $\mathrm{CaCO} 3$-MgCO 3. American Journal of Science 253 (5):274-282. doi:10.2475/ajs.253.5.274 
Hashimoto H, Komaki E, Hayashi F, Uematsu T (1980) Partial decomposition of dolomite in $\mathrm{CO}_{2}$. J Solid State Chem 33 (2):181-188. doi:10.1016/0022-4596(80)90118-8

Irving AJ, Wyllie PJ (1975) Subsolidus and melting relationships for calcite, magnesite and the join CaCO3-MgCO3 36 kb. Geochim Cosmochim Acta 39 (1):35-53. doi:https://doi.org/10.1016/0016-7037(75)90183-0

Jenkins DM, Holmes ZF, Ishida K, Manuel PD (2018) Autocorrelation analysis of the infrared spectra of synthetic and biogenic carbonates along the calcite-dolomite join. Phys Chem Miner 45 (6):563-574. doi:10.1007/s00269-018-0942-5

Lacivita V, D'Arco P, Mustapha S, Faria Bernardes D (2017) On the use of the symmetry-adapted Monte Carlo for an effective sampling of large configuration spaces. The test cases of calcite structured carbonates and melilites. Computational Materials Science 126:217-227. doi:https://doi.org/10.1016/j.commatsci.2016.09.037

Larsson AK, Christy AG (2008) On twinning and microstructures in calcite and dolomite. Am Mineral 93 (1):103-113. doi:10.2138/am.2008.2520

Markgraf SA, Reeder RJ (1985) High temperature structure refinements of calcite and magnesite. Am Mineral 70 (5-6):590-600

Maslen EN, Streltsov VA, Streltsova NR, Ishizawa N (1995) Electron density and optical anisotropy in rhombohedral carbonates. III. Synchrotron X-ray studies of $\mathrm{CaCO} 3, \mathrm{MgCO} 3$ and $\mathrm{MnCO}$. Acta Crystallographica Section B 51 (6):929-939. doi:doi:10.1107/S0108768195006434

Meike A, Wenk HR, Okeefe MA, Gronsky R (1988) Atomic resolution microscopy of carbonates interpretation of contrast. Phys Chem Miner 15 (5):427-437. doi:10.1007/bf00311121

Merlini M, Sapelli F, Fumagalli P, Gatta GD, Lotti P, Tumiati S, Abdellatief M, Lausi A, Plaisier J, Hanfland M, Crichton W, Chantel J, Guignard J, Meneghini C, Pavese A, Poli S (2016) Hightemperature and high-pressure behavior of carbonates in the ternary diagram $\mathrm{CaCO}-$ MgCO3-FeCO3. Am Mineral 101 (6):1423-1430. doi:10.2138/am-2016-5458

Newton RC, Goldsmith JR, Smith JV (1969) Aragonite crystallization from strained calcite at reduced pressures and its bearing on aragonite in low-grade metamorphism. Contrib Mineral Petrol 22 (4):335-348. doi:10.1007/BF00400128

Paquette J, Reeder RJ (1990) Single crystal X-ray structure refinements of 2 biogenic magnesian calcite crystals Am Mineral 75 (9-10):1151-1158

Perrin J, Vielzeuf D, Laporte D, Ricolleau A, Rossman GR, Floquet N (2016) Raman characterization of synthetic magnesian calcites. Am Mineral 101 (11):2525-2538. doi:10.2138/am-2016-5714

Putnis A (1992) An Introduction to Mineral Sciences. Cambridge University Press,

Radha AV, Kamath PV, Shivakumara C (2007) Order and disorder among the layered double hydroxides: combined Rietveld and DIFFaX approach. Acta Crystallographica Section B 63 (2):243-250. doi:doi:10.1107/S010876810700122X

Reeder RJ (1983) Crystal chemistry of the rhombohedral carbonates. Reviews in Mineralogy and Geochemistry 11 (1):1-47

Reeder RJ (1992) Carbonates; growth and alteration microstructures. Reviews in Mineralogy and Geochemistry 27 (1):380-424

Reeder RJ (2000) Constraints on Cation Order in Calcium-rich Sedimentary Dolomite. Aquatic Geochemistry 6 (2):213-226. doi:10.1023/a:1009659122772

Reeder RJ, Markgraf SA (1986) High-temperature crystal chemistry of dolomite. Am Mineral 71 (56):795-804

Reeder RJ, Nakajima Y (1982) The nature of ordering and ordering defects in dolomite. Phys Chem Miner 8 (1):29-35. doi:10.1007/BF00311160

Reeder RJ, Wenk H-R (1983) Structure refinements of some thermally disordered dolomites. Am Mineral 68 (7-8):769-776

Reksten K (1990) Superstructures in calcite. Am Mineral 75 (7-8):807-812 
Rietveld HM (1969) A Profile Refinement Method for Nuclear and Magnetic Structures. J Appl Crystallogr 2:65

Rodriguez-Carvajal J (1993) FullProf: A Program for Rietveld Refinement and Profile Matching Analysis of Complex Powder Diffraction Patterns (ILL). Physica B 192:55

Rodriguez-Navarro C, Kudlacz K, Ruiz-Agudo E (2012) The mechanism of thermal decomposition of dolomite: New insights from 2D-XRD and TEM analyses. Am Mineral 97 (1):38-51. doi:10.2138/am.2011.3813

Rodriguez-Navarro C, Ruiz-Agudo E, Nieto F, Livi KJT, Oberti R (2013) Carbonates: An overview of recent TEM research. In: Minerals at the Nanoscale. Mineralogical Society of Great Britain and Ireland, p 0. doi:10.1180/EMU-notes.14.10

Roisnel T, Rodriguez-Carvajal J (2001) WinPLOTR: A Windows tool for powder diffraction pattern analysis. In: Delhez R, Mittemeijer EJ (eds) Epdic 7: European Powder Diffraction, Pts 1 and 2, vol 378-3. Materials Science Forum. Trans Tech Publications Ltd, Zurich-Uetikon, pp 118-123. doi:10.4028/www.scientific.net/MSF.378-381.118

Scherrer P (1918) Bestimmung der Grösse und der inneren Struktur von Kolloidteilchen mittels Röntgenstrahlen. Nachr Ges WissGöttingen 26:98-100

Shen ZZ, Konishi H, Szlufarska I, Brown PE, Xu HF (2014) Z-contrast imaging and ab initio study on "d" superstructure in sedimentary dolomite. Am Mineral 99 (7):1413-1419. doi:10.2138/am.2014.4647

Stokes AR, Wilson AJC (1942) A method of calculating the integral breadths of Debye-Scherrer lines. Mathematical Proceedings of the Cambridge Philosophical Society 38 (3):313-322. doi:10.1017/S0305004100021988

Valverde JM, Perejon A, Medina S, Perez-Maqueda LA (2015) Thermal decomposition of dolomite under CO2: insights from TGA and in situ XRD analysis. PCCP 17 (44):30162-30176. doi:10.1039/C5CP05596B

Van Tendeloo G, Wenk HR, Gronsky R (1985) Modulated structures in calcian dolomite - a study by electron-microscopy. Phys Chem Miner 12 (6):333-341. doi:10.1007/bf00654343

Wang ML, Shi GH, Qin JQ, Bai Q (2018) Thermal behaviour of calcite-structure carbonates: a powder X-ray diffraction study between 83 and 618K. Eur J Mineral 30 (5):939-949. doi:10.1127/ejm/2018/0030-2768

Wang Q, Grau-Crespo R, de Leeuw NH (2011) Mixing Thermodynamics of the Calcite-Structured (Mn, $\mathrm{Ca}$ )CO3 Solid Solution: A Computer Simulation Study. The Journal of Physical Chemistry B 115 (47):13854-13861. doi:10.1021/jp200378q

Warren BE, Averbach BL, Roberts BW (1951) Atomic Size Effect in the X-Ray Scattering by Alloys. J Appl Phys 22 (12):1493-1496. doi:10.1063/1.1699898

Wenk H-R, Barber DJ, Reeder RJ (1983) Microstructures in carbonates. Reviews in Mineralogy and Geochemistry 11 (1):301-367

Wenk HR, Hu MS, Lindsey T, Morris JW (1991) Superstructures in ankerite and calcite. Phys Chem Miner 17 (6):527-539

Williamson GK, Hall WH (1953) X-ray line broadening from filed aluminium and wolfram. Acta Metall 1 (1):22-31. doi:https://doi.org/10.1016/0001-6160(53)90006-6

Zhang F, Xu H, Konishi H, Roden EE (2010) A relationship between d104 value and composition in the calcite-disordered dolomite solid-solution series. Am Mineral 95 (11-12):1650-1656. doi:10.2138/am.2010.3414

Zucchini A, Comodi P, Katerinopoulou A, Balic-Zunic T, McCammon C, Frondini F (2012) Orderdisorder-reorder process in thermally treated dolomite samples: a combined powder and single-crystal X-ray diffraction study. Phys Chem Miner 39 (4):319-328. doi:10.1007/s00269012-0489-9 
